\title{
Review \\ Regulation of B-Cell Receptor Signaling and Its Therapeutic Relevance in Aggressive B-Cell Lymphomas
}

\author{
Núria Profitós-Pelejà ${ }^{1,+}\left(\mathbb{D}\right.$, Juliana Carvalho Santos ${ }^{1,+}\left(\mathbb{D}\right.$, Ana Marín-Niebla ${ }^{2} \mathbb{D}$, Gaël Roué $1, *(\mathbb{D})$ \\ and Marcelo Lima Ribeiro 1,3
}

1 Lymphoma Translational Group, Josep Carreras Leukaemia Research Institute (IJC), 08916 Badalona, Spain; nprofitos@carrerasresearch.org (N.P.-P.); jcarvalho@carrerasresearch.org (J.C.S.); mlima@carrerasresearch.org (M.L.R.)

2 Department of Hematology, Experimental Hematology, Vall d'Hebron Institute of Oncology (VHIO), Vall d'Hebron Barcelona Hospital Campus, Vall d'Hebron University Hospital, 08035 Barcelona, Spain; ana.marin@vhebron.net

3 Laboratory of Immunopharmacology and Molecular Biology, Sao Francisco University Medical School, Braganca Paulista 12916-900, Brazil

* Correspondence: groue@carrerasresearch.org; Tel.: +34-935-572-835

+ These authors contributed equally to this work.

Citation: Profitós-Pelejà, N.; Santos, J.C.; Marín-Niebla, A.; Roué, G.; Ribeiro, M.L. Regulation of B-Cell Receptor Signaling and Its

Therapeutic Relevance in Aggressive B-Cell Lymphomas. Cancers 2022, 14, 860. https://doi.org/10.3390/ cancers 14040860

Academic Editor: Lorenzo Leoncini

Received: 30 December 2021

Accepted: 7 February 2022

Published: 9 February 2022

Publisher's Note: MDPI stays neutral with regard to jurisdictional claims in published maps and institutional affiliations.

Copyright: (C) 2022 by the authors. Licensee MDPI, Basel, Switzerland. This article is an open access article distributed under the terms and conditions of the Creative Commons Attribution (CC BY) license (https:// creativecommons.org/licenses/by/ $4.0 /)$.
Simple Summary: Dysregulated B-cell receptor (BCR) signaling is considered a potent contributor to tumor survival in different subtypes of B-cell non-Hodgkin lymphomas (B-NHLs). In the last decade, BCR-targeted therapies have emerged as promising alternative treatment options to standard chemoimmunotherapy. Despite the initial excitement and strong biological rationale, BCR-targeting drugs often fail to produce durable responses. This review will discuss the current understanding of the role of BCR signaling in B-NHLs. In addition, the mechanisms of action of BCR-targeted therapies, and how our actual knowledge supports the development of more specific inhibitors and new, rationally based, combination therapies, will also be discussed.

\begin{abstract}
The proliferation and survival signals emanating from the B-cell receptor (BCR) constitute a crucial aspect of mature lymphocyte's life. Dysregulated BCR signaling is considered a potent contributor to tumor survival in different subtypes of B-cell non-Hodgkin lymphomas (B-NHLs). In the last decade, the emergence of BCR-associated kinases as rational therapeutic targets has led to the development and approval of several small molecule inhibitors targeting either Bruton's tyrosine kinase (BTK), spleen tyrosine kinase (SYK), or phosphatidylinositol 3 kinase (PI3K), offering alternative treatment options to standard chemoimmunotherapy, and making some of these drugs valuable assets in the anti-lymphoma armamentarium. Despite their initial effectiveness, these precision medicine strategies are limited by primary resistance in aggressive B-cell lymphoma such as diffuse large B-cell lymphoma (DLBCL) and mantle cell lymphoma (MCL), especially in the case of first generation BTK inhibitors. In these patients, BCR-targeting drugs often fail to produce durable responses, and nearly all cases eventually progress with a dismal outcome, due to secondary resistance. This review will discuss our current understanding of the role of antigen-dependent and antigen-independent BCR signaling in DLBCL and MCL and will cover both approved inhibitors and investigational molecules being evaluated in early preclinical studies. We will discuss how the mechanisms of action of these molecules, and their off/on-target effects can influence their effectiveness and lead to toxicity, and how our actual knowledge supports the development of more specific inhibitors and new, rationally based, combination therapies, for the management of MCL and DLBCL patients.
\end{abstract}

Keywords: B-cell non-Hodgkin lymphoma (B-NHL); B-cell receptor (BCR); Bruton's tyrosine kinase (BTK); spleen tyrosine kinase (SYK); phosphoinositide-3-kinase (PI3K); ibrutinib; acalabrutinib; combination therapies 


\section{Introduction}

The introduction of massive sequencing approaches together with the development of more physiological preclinical models, has recently allowed a deeper understanding of the relevance of B-cell signaling pathways in the molecular pathogenesis of B-cell non-Hodgkin lymphoma (B-NHL). These advances provided significant insights into the differential response to standard immunotherapeutic regimens across the most aggressive B-NHL subtypes, including diffuse large B-cell lymphoma (DLBCL) and mantle cell lymphoma (MCL), and yielded several promising targets for novel antitumor therapies for these lifethreatening diseases. As a result, in the last two decades the treatment landscape of MCL, and to a lesser extent, DLBCL, has expanded from conventional cytotoxic chemotherapies to encompass targeted small-molecule drugs, monoclonal antibodies, antibody-drug conjugates, and cellular therapies. Among these new approaches, a significant proportion of MCLs and DLBCLs have been shown to be addicted to B-cell receptor (BCR) signaling, and/or to its downstream oncogenic pathways such as nuclear factor $-\kappa \mathrm{B}(\mathrm{NF}-\kappa \mathrm{B})$ and phosphatidylinositol 3-kinase (PI3K). Based on these observations, various specific inhibitors targeting these signaling cascades have been developed and evaluated in the clinics, essentially in patients with relapsed and/or refractory $(R / R)$ disease. In the following chapters, we provide an overview of current understanding on the role of the BCR pathway in lymphomagenesis, with a special focus on Bruton's tyrosine kinase (BTK) and PI3K downstream signaling. We also summarize the available data on the clinical activity and the potential mechanisms of resistance to BTK and PI3K inhibitors in these diseases, either as monotherapies or in combination with other biological agents.

\section{Main Characteristics of Aggressive B-Cell Lymphoma}

DLBCL and MCL represent clinically and molecularly heterogeneous malignancies of aggressive B-NHL. Thirty to forty percent of all newly diagnosed B-NHL cases in the Western world are DLBCL, the most common B-NHL neoplasm [1,2]. DLBCL subtypes are classified by cell-of-origin, genetic and molecular features. According to the cell-oforigin, DLBCL can be classified as germinal center B-cell-like (GCB) or activated B-cell-like (ABC) subtypes. GCB and ABC subtypes have distinct genomic alterations and clinical outcomes [3]. GCB-DLBCL presents intra-clonal heterogeneity, somatic hypermutation, and CD10 and B-Cell Lymphoma 6 (BCL-6) expression, while ABC-DLBCL has constitutive activity of NF-kB and expression of B-Cell Lymphoma 2 (BCL-2) and Interferon Regulatory Factor 4 (IRF4) [4]. The molecular stratification of DLBCL is defined as double-hit or triple-hit lymphoma depending on MYC and BCL2 and/or BCL6 rearrangements [5]. Despite of high heterogeneity, these patients usually present a poor prognosis after frontline treatment [6,7]. Several studies based on whole-exome sequencing analysis further identify new genetic DLBCL subtypes according to recurrent mutations in MYD88, CD79, NOTCH1, NOTCH2, EZH2 and BCL2 genes [4]. Unfortunately, more than half of DLBCL patients experience disease progression after first line treatment and most patients with $R / R$ DLBCL are largely incurable.

MCL is a B-NHL that accounts for up to $7 \%$ of malignant lymphomas in Western Europe with an incidence rate of about 2 per 100,000 individuals every year [8]. Different molecular mechanisms drive the disease evolution resulting in a highly heterogeneous clinical behavior. The primary oncogenic event in MCL development is the chromosomal translocation $\mathrm{t}(11 ; 14)(\mathrm{q} 13 ; \mathrm{q} 32)$ which leads to the constitutive overexpression of the cell cycle regulator cyclin D1 [9]. The tumors are classified as nodal or conventional MCL, which represents $80-90 \%$ of cases and has a worse prognosis, and as non-nodal leukemic MCL, accounting for $10-20 \%$ of cases presenting an indolent biological behavior. These two subtypes have different genetic and molecular features. Nodal MCL tumors are characterized by unmutated immunoglobulin heavy chain variable region genes (IGHV) and by the transcription factor sex-determining region Y-box 11 (SOX11) overexpression, while non-nodal MCL typically harbor IGHV mutation and no SOX11 expression [10]. Although the median overall survival (OS) of MCL patients is 5-7 years [11], major advances 
in the treatment have been achieved in the last few years with the advent of novel targeted agents such as BTK inhibitors (BTKi).

\section{B-Cell Receptor (BCR) Signaling}

\subsection{Physiological Roles of BCR Signaling}

The BCR complex is essential for B-cell development and function. The BCR consists of a transmembrane immunoglobulin complex essential for the antigen binding on the surface of B lymphocytes and plays a key role in immune response, cell growth, adhesion, differentiation, survival, cytoskeletal remodeling, and apoptosis [12,13]. The rearrangement of immunoglobulin heavy chain variable (V), diversity (D), and joining (J) gene segments in the progenitor $B$ cells give rise to the pre-BCR which, in turn, mediate signal cascade for immature B-cell development. In the dark zone germinal center (GC), mature B cells undergo somatic hypermutation leading to the complete BCR affinity maturation. Then, these B cells experience class-switch recombination and become memory B cells or antibody secreting plasma cells. Following a pathogen infection, B cells use the BCRs to recognize and bind to the antigenic epitopes resulting in the secretion of specific antibodies as an early attempt to neutralize the foreign antigen or secreting cytokines to attract other immune cells [14].

The BCR exerts its function through tonic or antigen-dependent BCR signaling pathways. Tonic BCR signaling is essential for the downstream survival signal of resting $\mathrm{B}$ cells and is mediated by phosphatidylinositol 3 kinase (PI3K)/AKT/forkhead box class $\mathrm{O}$ family member transcription factors (FOXO)/mammalian target of rapamycin (mTOR) pathways $[15,16]$.

The BCRs harbor the $\operatorname{Ig} \alpha(\mathrm{CD} 79 \mathrm{a}) / \operatorname{Ig} \beta(\mathrm{CD} 79 \mathrm{~b})$ heterodimer with an immunoreceptor tyrosine-based activation motifs (ITAMs) that are phosphorylated upon antigen-dependent BCR signaling activation [17]. BCR-antigen microclusters are associated with lipid on the plasma membrane leading to phosphorylation of BCR's ITAMs by Src kinases, which drive the recruitment of downstream signaling pathways such as spleen tyrosine kinase (SYK) and BTK. SYK, in turn, phosphorylates the adaptor proteins as BLNK, SHC, and BCAP, which then recruit other signaling molecules [18]. The BCR signal transduction is further propagated by PI3K, Rho family kinases, mitogen-activated protein (MAP) kinases, and transcription factors, such as NF-KB [19-22]. On the other hand, the BCR signal transduction can be inhibited through dephosphorylation of BCR components by phosphatases, such as protein tyrosine phosphatase non-receptor type 22 (PTPN22), Protein Tyrosine Phosphatase Non-Receptor Type 6 (PTPN6), and Phosphatase and Tensin Homolog (PTEN) [23,24].

B-cell development, differentiation and maturation, co-stimulatory protein expression, migration, and apoptosis are tightly regulated by BTK upon BCR stimulation [25-27]. BTK is a non-receptor cytoplasmic Tec tyrosine kinase protein that harbors a kinase domain, two SRC homology domains (SH2 and SH3), a N-terminal pleckstrin (PH) domain, and a TEC domain. The BCR stimulation leads to a downstream cascade guided by BTK activation through transphosphorylation at Y551 in the catalytic domain, and autophosphorylation at Y223 in the SH3 domain [28,29]. Upon its activation, BTK starts a phosphorylation positive feedback loop with phospholipase C- $\gamma$ (PLC $\gamma 2)$, which in turn, regulate downstream mediators such as the MAPK pathway and transcription of nuclear factor of activated T-cells (NFAT) [30]. Considering that aberrant activation of BTK has been associated with the pathogenesis of several B-cell malignancies [31], BTK inhibition has been shown to be an attractive therapeutic approach for the treatment of B-cell disorders.

\subsection{Dysregulated BCR Signaling in Aggressive B-Cell Lymphomas}

Genetic alterations that lead to constitutive BCR activation have been associated to B-NHL development. Antigen-dependent immunoglobulin genes rearrangements/chromosomal translocations, chronic active, and tonic BCR signaling deregulation often occur in normal B cells, which may lead to B-cell malignant transformation. Most B-cell lymphomas still 
express a BCR and share the same survival signals supplied by BCR expression in normal B cells to promote the survival of tumor cells [9].

Antigen's recognition causes Ig genes somatic hypermutations and chromosomal translocations that may lead to pathological BCR activation (Figure 1). Some oncogenic signaling pathways such as PI3K and NFKB are activated by IgM resulting in survival and proliferation of B cells, while MAPK and ERK signaling pathways are activated by IgG resulting in plasmocytic differentiation [32]. The BCR signaling deregulation has been implicated in several types of lymphomas, such as chronic lymphocytic leukemia/small lymphocytic lymphoma (CLL/SLL), follicular lymphoma (FL), marginal zone lymphoma (MZL), and MCL [33-36]. Antigen-associated lymphoproliferative disorders may arise from the expansion of reactive B cells, as suggested by autoantigen-dependent BCR activation in ABC-DLBCL, Helicobacter pylori-driven gastric MALT lymphoma and hepatitis C-driven splenic MZLs [37,38]. The BCR engagement by self-antigens is evidenced by the presence of BCR clusters on the ABC-DLBCL cell surface as well as the epidemiological studies supporting that several autoimmune diseases are risk factors for the DLBCL development, suggests that B-cells auto reactivity might be implicated in B-cell malignant transformation [39].

\section{Antigen-dependent \& chronic BCR signaling}

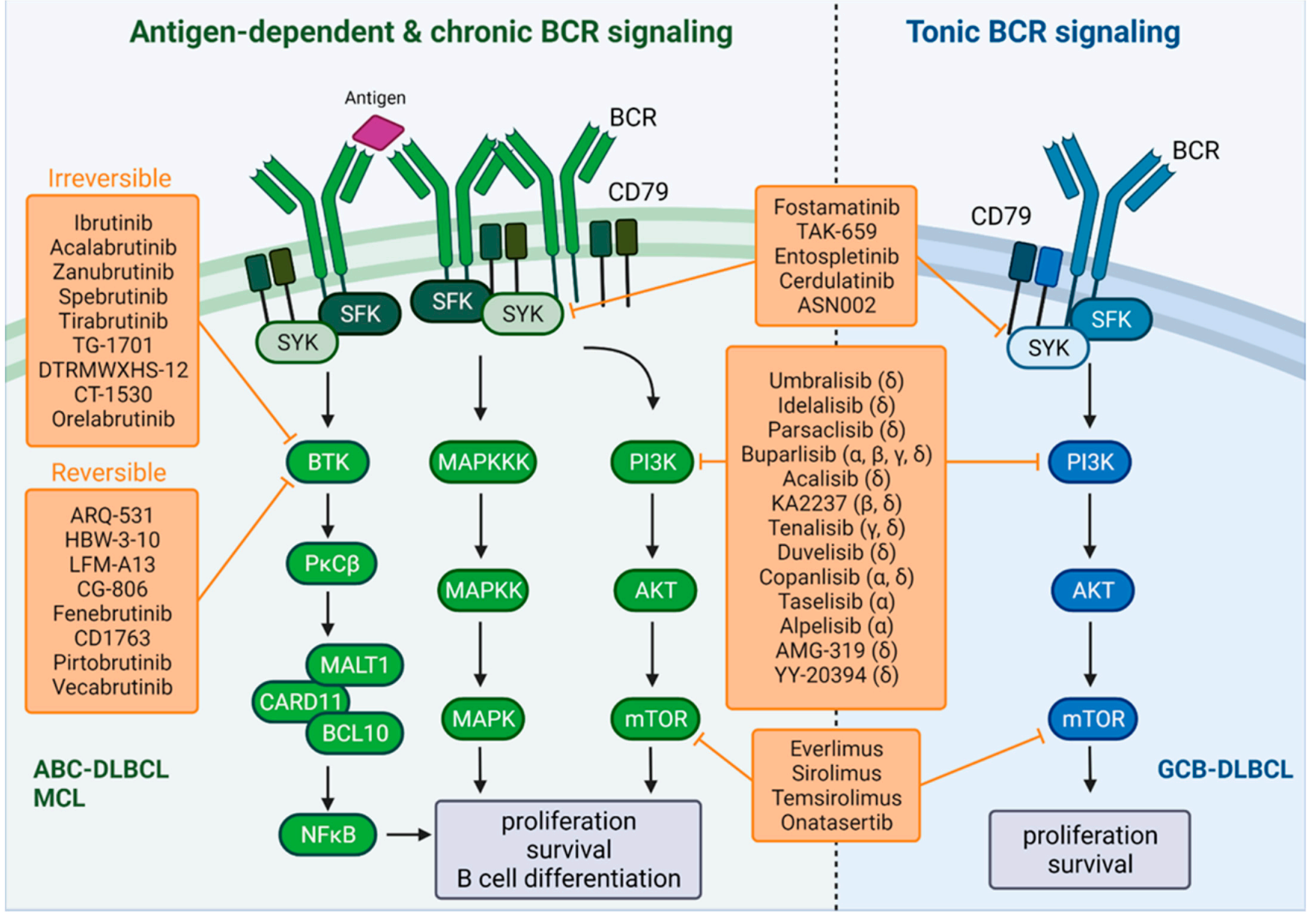

Figure 1. Regulation of BCR signaling and the therapeutic inhibition of BTK and PI3K in DLBCL and MCL. (Left panel) Antigen-dependent and chronic active BCR signaling; (Right panel) Tonic BCR signaling.

It has been shown that ABC-DLBCL displays chronic active BCR signaling resulting in constitutive NF- $\mathrm{B}$ activity [40] (Figure 1). A variety of mechanisms are involved in this aberrant activity, including mutations in $C A R D 11$, found in approximately $10 \%$ of ABC-DLBCL; loss of function mutations in A20 (a NF- $\mathrm{KB}$ negative regulator), found 
in about $24 \%$ of ABC-DLBCL; and ITAM mutations, present in approximately $20 \%$ of ABC-DLBCL, which prevent BCR endocytosis and cause an increase in BCR expression and a decrease in LYN kinase activity [40-42]. The adaptor protein myeloid differentiation primary response 88 (MYD88) is critical for NF-kB activation downstream of Toll-like receptors (TLRs) and has also been frequently mutated in ABC-DLBCL [43]. The multiprotein super-complex formed by MYD88-TLR9-BCR, characterized by ibrutinib responsiveness, has been shown to co-localize with mTOR on endolysosomes, where it drives pro-survival signaling in ABC-DLBCL through NF- $\mathrm{kB}$ and mTOR activation [44]. On the other hand, another recent study based on in vitro DLBCL model showed that a loss of KLHL14, a negative $B C R$ regulator found to be mutated in about $10 \%$ of $A B C-D L B C L$, induces the NF- $\kappa B$ pathway by activating the MYD88-TLR9-BCR super-complex, which confers relative resistance to the first-in-class BTKi ibrutinib [45].

Similarly, constitutive BCR signaling is also associated with the activation of the canonical and non-canonical NF- $\mathrm{kB}$ pathways in MCL in both in vitro and in vivo models which is correlated with poor survival $[46,47]$. Genetic aberrations have also been linked to constitutive BCR-NF- $\mathrm{KB}$ signaling in MCL cases. Somatic mutations affecting BIRC3 and TRAF2, negative regulators of the non-canonical NF-kB pathway, are associated with BTKi resistance [46]. SYK overexpression has been reported in the MCL cell lines and in patient-derived samples [48]. Furthermore, gain-of-function mutations in CARD11 have been described particularly in relapsed MCL more often than at diagnosis [49]. Similar to ABC-DLBCL, the analysis of $29 \mathrm{MCL}$ cases showed that A20 is also frequently deleted $(31 \%)$ or promoter-methylated (37,5\%); however, the expression level of A20 was unrelated to the genomic status of MCL [50].

In contrast to antigen and chronic active $\mathrm{BCR}$ signaling, the antigen-independent signal, termed 'tonic BCR signaling', is mediated by PI3K $\alpha$ and PI3K $\delta / A K T / m T O R$, but not the NF- $\mathrm{KB}$ pathway, to promote the proliferation and survival of malignant $B$ cells [30] (Figure 1). Genomic data have shown that GCB-DLBCL lines exclusively use tonic BCR signaling [51]. In normal B cells, SYK regulates PI3K signaling through its interaction with the p85 subunit of PI3K and by the phosphorylation of CD19 (essential for GCB cells) and $B C A P$ (essential for $A B C$ cells) [52]. It has been suggested that tonic BCR signal is also transmitted via SYK to activate the PI3K pathway in GCB-DLBCL. Some evidence show that GCB-DLBCL cells are sensitive to SYK inhibition and that SYK blockage decreases $\mathrm{BCR} / \mathrm{PI} 3 \mathrm{~K} / \mathrm{AKT}$ activity, decreases the proliferation and induces apoptosis $[53,54]$. In mature B cells, BCR-induced activation of PI3K leads to FOXO phosphorylation by AKT causing its transcriptional repression [55]. Based on tonic BCR signaling-dependent DLBCL model, Szydlowski et al. demonstrated that SYK inhibition decreases AKT activity and eventually leads to FOXO1-mediated cell death [56]. Moreover, CRISPR analysis revealed that GCB-DLBCL cells are dependent on the BCR signaling components CD79A, CD79B, LYN, CD19, and CD81 for their survival [44]. Using the same approach, Havranek et al. showed that tonic BCR signaling is tightly regulated by $\mathrm{Y} 188 \mathrm{~F}$ mutation in CD79A, PTEN protein expression and BCR surface density in GCB-DLBCL cells [51]. In aggressive MCL, the constitutive activation of the PI3K/AKT axis has also been associated to impaired PTEN [57], supporting the synergy between the blockage of BTK and the PI3K/mTOR/Akt pathways found in MCL cases.

\section{Pharmacological Targeting of BCR Upstream Kinases and Its Limitations in MCL and DLBCL}

\subsection{Preclinical Drug Development}

Studies targeting BTK have attracted substantial attention due to its crucial role in the BCR pathway and BTKi have shown promising antitumor activities, both in vivo and in vitro models. According to its mechanism of action and their binding affinity and activity, the BTKi are classified into two types: irreversible inhibitors, where they bind to the amino acid residue Cys481 forming a covalent bond; or the reversible inhibitors, which bind to an inactive conformation of the kinase, by accessing the specific SH3 pocket of BTK [58]. 
The majority of BTKi are irreversible inhibitors, from which the first-generation inhibitor is ibrutinib. In 2010, ibrutinib was demonstrated to have selective toxicity in DLBCL cell lines with chronically active BCR signaling with sub-nanomolar activity $\left(\mathrm{IC}_{50}=0.5 \mathrm{nM}\right)$, by preventing the BTK autophosphorylation [40] and in vivo data confirmed its potential [59]. Ibrutinib, when combined with bortezomib, also presented a synergism by enhancing apoptosis in DLBCL and MCL cells through AKT and NFKB inactivation [60], while in DLBCL it showed cumulative antitumor effects with other agents, such as enzastaurin [61] or lenalidomide [62]. Together these preclinical studies provided detailed insights into the mechanism of action for the subsequent clinical trials (described below).

The off-target side effects of ibrutinib have led to the development of second-generation inhibitors of which acalabrutinib demonstrated to have less off-target kinases inhibition [63] and also to be more potent in in vitro assays and in vivo canine models of DLBCL and xenograft models derived from ABC-DLBCL and MCL [63-65]. Another more selective inhibitor is zanubrutinib, which also showed antitumor activity in the nanomolar range in MCL cell lines as well as in ABC-DLBCL cells, with a similar effect as ibrutinib but with less off-target effects and prolonged overall survival in a DLBCL xenograft model $[66,67]$. Alternative irreversible BTKi are M2951 and M7583, presenting an in vivo antitumor activity in preclinical models of ABC-DLBCL [68]; spebrutinib (CC-292), with high efficacy as a single agent as well as in synergistic combinations in ABC-DLBCL, but limited efficacy in GCB-DLBCL [69]; tirabrutinib (ONO/GS-4059), which is showing promising results in preclinical studies [70,71]; TG-1701, a more selective inhibitor, presenting Ikaros as an important biomarker for response and efficacy, both in vitro and in vivo [72]; and other compounds, currently under development with promising results in vitro, such as QL47 [73].

However, primary and secondary resistances have emerged from the irreversible BTKi ibrutinib, resulting in a poorer prognosis of relapsed lymphoma patients. In DLBCL and MCL the mechanisms of resistance are not as well-known as in CLL, where the cause of resistance has been identified to be related in part to mutations at the covalent site (C481) on BTK and also PLC $\gamma 2$, resulting in a downstream signal activation [74].

To overcome the irreversible BTKi limitations (off-target side effects and long-term toxicities), new reversible compounds are under development that will be helpful for the ibrutinibresistant patients. Some of the most relevant reversible inhibitors are ARQ-531, which have demonstrated potent activity against both BTK wild-type and C481S mutant in ABC-and GCB-DLBCL cell lines [75,76]; LFM-A13, a dual inhibitor against BTK and PLK [77]; HBW-3-10, with great potency and pharmacokinetic profile and better results than the ibrutinib, when compared in xenograft models [78]; fenebrutinib, a potent reversible inhibitor against BTK C4815 mutant [79], CG-806, with great effects in MCL and DLBCL in vitro and MCL PDX mice models [80], CB1763, with a strong effect on C481S mutant BTK [81]; and Pirtobrutinib (LOXO-305), with potent antitumor effects both in vitro and in vivo [82,83].

Another interesting novel strategy to overcome ibrutinib resistance is the proteolysistargeting chimera (PROTAC), which will selectively target BTK C481S mutant. L18I has been reported to inhibit proliferation in BTK mutant DLBCL cell lines and induce rapid tumor regression in C481S BTK HBL-1 xenograft tumors [84]. In addition, P13I and compound 6e, are under development in preclinical studies with promising results [85-88].

The next key component of the BCR signaling pathway, which has gained relevance as a therapeutic target, is SYK. R406 is a SYK inhibitor that induces apoptosis in the majority of DLBCL cell lines studied by the inhibition of both tonic and induced BCR signaling [53]; however, it also inhibits other kinases [89]. Its oral prodrug is R788, fostamatinib, which has shown great efficiency in B-NHL-like mice models and is currently in clinical trials (see below) [90,91]. Another SYK inhibitor is cerdulatinib, which has demonstrated great antitumor activity by inducing apoptosis and cell cycle arrest in both ABC- and GCB-DLBCL cell lines [92]. Similar results were being observed for PRT060318, where the cell cycle arrest effect by the inhibitor was mimicked by a genetic reduction of SYK using a siRNA [89]. Entospletinib (GS-9973) selectively inhibits SYK and presents a synergistic antitumor effect with vincristine, both in a panel of DLBCL cell lines and in a DLBCL tumor xenograft 
model [93]. TAK-659 is a dual SYK/FLT-3 inhibitor with antitumor activity in DLBCL cell line xenograft models and in patient-derived xenografts (PDX) [94,95]. ASN002 is a dual JAK/SYK inhibitor, showing a great antiproliferative activity in in vitro and in in vivo models. Moreover, it also showed antitumor activity in ibrutinib-resistant cell lines [96].

Another strategy, which has shown effective preclinical results is the inhibition of PI3K pathway, usually in combination with other treatments. These inhibitors can be divided into non-selective pan inhibitors, targeting all isoforms, or isoform-specific inhibitors, which are more selective and have fewer off-target effects [97]. There are several pan inhibitors, of which we highlight buparlisib, with a subnanomolar activity against $\mathrm{PI} 3 \mathrm{~K} \alpha, \beta, \gamma$, and $\delta$ [98]; copanlisib, a second-generation inhibitor against the $\alpha$ and $\delta$ isoforms $[99,100]$; KA2237, against the $\alpha$ and $\beta$ isoforms and with tumorigenic properties in both sensitive- and ibrutinib-resistant cells in MCL cell lines and PDX tumors [101]; and tenalisib (RP6530), a dual PI3K $\delta / \gamma$ inhibitor with an enhanced antitumor response by targeting both lymphoma cells and its microenvironment [102]. In addition, there are isoform-specific inhibitors for $\mathrm{PI} 3 \mathrm{~K} \alpha$, such as taselisib (GDC-0032) with a synergistic antiproliferation activity in DLBCL cell lines when combined with venetoclax [103]; alpelisib, with a marginal response when used as a single agent [104] and BYL719, which combined with idelalisib cooperates and inhibitors the proliferation in ABC-DLBCL cell lines [105]. Regarding PI3K $\beta$ inhibitors, preclinical studies using DLBCL models treated with AZD6482, show a low antitumor activity as a single agent [104]. The PI3K $\gamma$ inhibitor JN-PK1 is currently under preclinical evaluation, showing inhibition of the proliferation in several lymphoma cell lines [106]. Finally, the predominant isoform in FL and DLBCL, and therefore the most studied for its inhibition is the PI3K $\delta$. From here, we will highlight several inhibitors such as idelalisib (CAL-101), which downregulated p-AKT and increased the expression of apoptosis markers in DLBCL, MCL, and FL cell lines [107]; duvelisib (IPI-145), with preclinical results showing an inhibition on tumor growth both in vitro and in PDX mice in MCL and synergism with other treatments [108,109]; umbralisib (TGR-1202), a PI3K $/$ CK1 inhibitor that has a synergistic cytotoxic effect when combined with a NF-kB inhibitor (carfilzomib) in MCL cell lines and also when combined with ublituximab (Anti-CD20 antibody) and TG-1801 (bi-specific anti-CD19/CD47 antibody) [110,111]; AMG319 which as a monotherapy has antitumor activity [50] and in combination with vincristine synergistically reduced proliferation in vitro and enhanced tumor regression in vivo in DLBCL [51]; and SHC014748M that is a novel compound with in vitro and in vivo efficacy in B-cell lymphoma cell lines [112].

Lastly, elevated or aberrant activation of mTOR has been identified in several cell lines and patient samples of DLBCL and MCL; thus, its targeting is a therapeutic approach alone or in combination [113]. Rapamycin, or sirolimus, is an antibiotic and the first mTOR inhibitor discovered, from which novel rapamycin analogs have emerged: temsirolimus that has shown antitumor activity in MCL cell lines [114]; and everolimus (RAD001), showing an effect associated with cell-cycle arrest in MCL [115]. To achieve a more potent anticancer activity, small molecules that inhibit both mTORC1 and mTORC2 have been developed. Among them, CC-223 is a potent and selective inhibitor that shows a better induction in apoptosis, when compared to rapamycin in a panel of DLBCL, FL, and MCL cell lines [116]. AZD014 has been shown to synergize with ibrutinib and cause tumor regression in in vivo experiments in ABC-DLBCL [117]. Finally, PQR309 is a dual PI3K/mTOR inhibitor with promise for advancing into clinical trials, alone or in combination with other treatments [118]. Figure 1 summarizes the main BCR signaling therapeutic targets in DLBCL and MCL.

\subsection{Clinical Experience with the Targeting of Apical BCR Kinases in DLBCL and MCL}

The arrival of ibrutinib to the therapeutic armamentarium of MCL was a real breakthrough and has changed the treatment paradigm in the relapsed/refractory $(R / R)$ setting. The first clinical results from the phase 2 pivotal study in heavily pre-treated MCL [119] led to an accelerated approval of ibrutinib for R/R MCL in 2013 by the U.S. Food and Drug Administration (FDA) and in 2014 by the European Medicines Agency (EMA). Ibrutinib 
showed an overall response (OR) and complete response $(\mathrm{CR})$ rates of $68 \%$ and $21 \%$, respectively, with a median duration of response (DOR) of 17.5 months, which were significantly higher than those observed with the previously approved targeted agents, bortezomib, temsirolimus, and lenalidomide, whose rates of OR and CR were $22-33 \%$ and $8-10 \%$, respectively, with median DOR ranging between 8 months with bortezomib [120] and temsirolimus [121-123] and 16 months with lenalidomide [124,125]. The phase 3 RAY study demonstrated the superiority of ibrutinib versus temsirolimus also in terms of progression free survival (PFS) (15.6 vs. 6.2 months) [126]. In addition, patients receiving ibrutinib on their first relapse showed a significantly higher PFS than those treated with ibrutinib in later relapses ( 25.4 vs. 10.3 months, respectively), which was an unexpected finding, not observed in the temsirolimus arm, where the PFS was the same for all the patients regardless of the number of previous lines received. Another study pooling together the data from up to 330 patients with R/R MCL prospectively included in two phase 2 trials and in the phase 3 RAY study confirmed that the sooner ibrutinib is used when patients with MCL relapse after the first line, the better the results will be in terms of PFS, but also of CR rate (32\% when ibrutinib was used after only one previous line versus $14 \%$ when used in later relapses), DOR (35.6 vs. 16.6 months with early vs. late use of ibrutinib) and overall survival (OS) (61.6 vs. 22.5 months) [127], leading to the current unanimous recommendation about the preferential use of ibrutinib as the first option in relapse, in order to get the most out of this active drug in R/R MCL.

Ibrutinib is a well-tolerated and safe drug, but the concern about its collateral effects on other kinases besides BTK, associated with a higher risk of bleeding (mostly grade $1-2$ events in the clinical practice) and cardiovascular events (atrial fibrillation and hypertension) led to the development of new generation BTKi with reduced off-target effects. Acalabrutinib and zanubrutinib are the first two of this new generation BTKi with an improved safety profile $[128,129]$ approved for patients with R/R MCL, with encouraging data on efficacy and survival confirming how this family of drugs has definitely changed the landscape of salvage treatment in MCL. Indeed, several newer, safer, and more potent BTKi are coming along, both covalent irreversible (such as acalabrutinib and zanubrutinib) and non-covalent reversible BTKi (such as pirtobrutinib and others), whose main clinical data are summarized in Table 1. In addition, recruiting information and preliminary results of clinical trials with targeted BCR inhibition as a single agent or combinatorial treatments are presented in Supplemental Table S1.

Table 1. Clinical trials with targeted BCR inhibition as single agent treatments.

\begin{tabular}{|c|c|c|c|c|c|c|c|c|}
\hline Targets & Drug/Regimen & Clinical Trial & Phase & Nb Pts & Status & Conditions & Response Data & References \\
\hline BTK & Acalabrutinib & NCT02112526 & 1 & 21 & Active & R/R DLBCL & $\begin{array}{l}\text { ORR } 24 \%, \text { CR } 19 \% \\
\text { AEs Grade } 3 / 444 \%\end{array}$ & [130] \\
\hline BTK & DTRMWXHS-12 & NCT02891590 & 1 & 13 & Completed & $\begin{array}{c}\text { R/R B-cell } \\
\text { Lymphomas }\end{array}$ & $\begin{array}{l}\text { Well-tolerated and } \\
\text { no DLT achieved }\end{array}$ & [131] \\
\hline BTK & Ibrutinib & NCT00849654 & 1 & 66 & Completed & $\begin{array}{c}\text { B-cell } \\
\text { Lymphomas }\end{array}$ & $\begin{array}{c}\text { ORR } 60 \% \\
\text { CR } 16 \% \\
\text { PFS } 13.6 \text { months }\end{array}$ & [132] \\
\hline BTK & Ibrutinib & NCT01704963 & 1 & 15 & Completed & $\begin{array}{c}\text { R/R B-cell } \\
\text { Lymphomas }\end{array}$ & ORR 73.3\% & [133] \\
\hline BTK & Ibrutinib & NCT01325701 & 2 & 78 & Completed & R/R DLBCL & $\begin{array}{l}\text { CR or PR in } 37 \% \\
(\mathrm{ABC}) \text { and in } 5 \% \\
(\mathrm{GCB})\end{array}$ & [134] \\
\hline BTK & Ibrutinib & NCT02207062 & 2 & 20 & Active & $\begin{array}{l}\text { R/R B-cell } \\
\text { Lymphomas }\end{array}$ & $\begin{array}{c}\text { ORR } 35 \% \\
\text { CR } 15 \% \\
\text { PFS } 4.1 \text { months } \\
\text { OS } 22.8 \text { months }\end{array}$ & [135] \\
\hline
\end{tabular}


Table 1. Cont.

\begin{tabular}{|c|c|c|c|c|c|c|c|c|}
\hline Targets & Drug/Regimen & Clinical Trial & Phase & Nb Pts & Status & Conditions & Response Data & References \\
\hline BTK & Ibrutinib & NCT01804686 & 3 & 700 & Active & $\begin{array}{l}\text { CLL, SLL, MCL, } \\
\text { FL DLBCL, WM }\end{array}$ & $\begin{array}{c}\text { CR } 27.6 \% \\
\text { PR } 42.2 \% \\
\text { PFS } 12.5 \text { months }\end{array}$ & [136] \\
\hline BTK & TG1701 & NCT03664297 & 1 & 86 & Active & $\begin{array}{c}\text { B-cell } \\
\text { Lymphomas }\end{array}$ & NA & NA \\
\hline BTK & Vecabrutinib & NCT03037645 & $1 \& 2$ & 39 & Terminated & $\begin{array}{l}\text { CLL, SLL, MCL, } \\
\text { WM, DLBCL, FL, } \\
\text { MZL }\end{array}$ & $\begin{array}{l}\text { Well tolerated but } \\
\text { terminated due to } \\
\text { insufficient } \\
\text { evidence of activity }\end{array}$ & NA \\
\hline BTK & Zanubrutinib & NCT03189524 & 1 & 44 & Completed & $\mathrm{R} / \mathrm{R} \mathrm{MCL}$ & $\begin{array}{c}\text { CR } 86.6 \% \\
\text { DOR } 19.5 \text { months } \\
\text { PFS } 22.1 \text { months }\end{array}$ & [129] \\
\hline BTK & Zanubrutinib & NCT03145064 & 2 & 41 & Completed & DLBCL & $\begin{array}{c}\text { ORR } 29.3 \% \\
\text { CR } 17.1 \% \\
\text { DOR } 4.5 \text { months } \\
\text { PFS } 2.8 \text { months? }\end{array}$ & [137] \\
\hline mTOR & Onatasertib & NCT01177397 & $1 \& 2$ & 173 & Completed & MM, DLBCL & $\begin{array}{l}\text { Acceptable safety } \\
\text { PR } 17.6 \%\end{array}$ & [138] \\
\hline PI3K & Acalisib & NCT01705847 & 1 & 39 & Completed & $\begin{array}{c}\text { B-cell } \\
\text { Lymphomas }\end{array}$ & $\begin{array}{c}\text { ORR } 28.6 \% \\
\text { AEs grade }>3 \\
55.3 \%\end{array}$ & [139] \\
\hline PI3K & AMG-319 & NCT01300026 & 1 & 28 & Completed & $\begin{array}{l}\text { CLL, DLBCL, } \\
\text { MCL }\end{array}$ & AEs grade > $325 \%$ & [140] \\
\hline PI3K & Buparlisib & NCT01693614 & 2 & 72 & Completed & DLBCL, MCL, FL & $\begin{array}{l}\text { ORR } 11.5 \% \text { in } \\
\text { DLBCL and } 22.7 \% \\
\text { in MCL }\end{array}$ & [141] \\
\hline PI3K & Buparlisib & NCT01719250 & Early 1 & 7 & Completed & $\begin{array}{l}\text { R/R DLBCL, } \\
\text { R/R FL, R/R } \\
\text { MCL }\end{array}$ & NA & NA \\
\hline PI3K & Fimepinostat & NCT01742988 & 1 & 106 & Completed & R/R DLBCL & $\begin{array}{l}\text { CR } 12.5 \% \\
\text { PR } 37.5 \% \\
\text { SD } 37.5 \% \\
\end{array}$ & [142] \\
\hline PI3K & Idelalisib & NCT03151057 & 1 & 60 & Active & $\begin{array}{l}\text { CLL, FL, MCL, } \\
\text { DLBCL }\end{array}$ & NA & NA \\
\hline PI3K & KA2237 & NCT02679196 & 1 & 23 & Completed & $\begin{array}{c}\text { B-cell } \\
\text { Lymphomas }\end{array}$ & $\begin{array}{c}\text { ORR } 37 \% \\
\text { AEs grade }>343 \%\end{array}$ & [143] \\
\hline PI3K & Parsaclisib & NCT03688152 & 1 & 9 & Completed & R/R DLBCL & NA & NA \\
\hline PI3K & Parsaclisib & NCT03314922 & 1 & 17 & Active & $\begin{array}{c}\text { B-cell } \\
\text { Lymphomas }\end{array}$ & NA & NA \\
\hline PI3K & Parsaclisib & NCT02998476 & 2 & 60 & Completed & R/R DLBCL & $\begin{array}{c}\text { ORR } 25.5 \% \\
\text { DOR } 6.2 \text { months }\end{array}$ & [144] \\
\hline PI3K & Tenalisib & NCT02017613 & 1 & 35 & Completed & $\begin{array}{c}\text { B-cell } \\
\text { Lymphomas }\end{array}$ & $\begin{array}{l}\text { ORR } 19 \% \\
\text { CR } 6 \% \\
\text { PR } 13 \%\end{array}$ & [145] \\
\hline PI3K & Umbralisib & NCT01767766 & 1 & 90 & Completed & NHL, CLL & $\begin{array}{c}\text { ORR } 24 \% \\
\text { CR } 8 \% \\
\text { PR } 16 \% \\
\text { AEs grade }>3 \text { in } \\
\text { less than } 5 \%\end{array}$ & {$[146,147]$} \\
\hline SYK & Fostamatinib & NCT00446095 & $1 \& 2$ & 81 & Completed & $\begin{array}{c}\text { B-cell } \\
\text { Lymphomas }\end{array}$ & $\begin{array}{c}\text { ORR } 22 \% \text { in } \\
\text { DLBCL and } 11 \% \text { in } \\
\text { MCL } \\
\text { PFS } 4.2 \text { months }\end{array}$ & [148] \\
\hline
\end{tabular}

Abbreviations: FL, follicular lymphoma; DLBCL, diffuse large B-cell lymphoma; $\mathrm{MCL}$, mantle cell lymphoma; MZL, marginal zone lymphoma; NHL, non-Hodgkin lymphoma; CLL, chronic lymphocytic leukemia; $\mathrm{MM}$, multiple myeloma; WM, waldenstrom's macroglobulinemia; ORR, overall response rate; CR, complete response; $\mathrm{PR}$, partial response; $\mathrm{SD}$, stable disease; $\mathrm{PD}$, progressive disease; $\mathrm{DOR}$, duration of response; PFS, progression-free survival; OS, overall survival; AEs, adverse effects; NA, not available. 
The clinical experience with PI3K inhibitors (PI3Ki) in MCL is far from that of BTKi and none of the PI3Ki tested in aggressive B-NHL (MCL or DLBCL), either $\delta$-selective or pan-PI3Ki, has been approved to date, mainly due to an insufficient efficacy in monotherapy. One of the most recently evaluated PI3Ki in MCL and DLBCL, parsaclisib, a $\delta$-selective PI3Ki with an improved toxicity profile, showed initial promising results in a phase $1 / 2$ study [149], which unfortunately were not confirmed later on in the respective phase 2 studies. The CITADEL-205 study in R/R MCL showed activity of parsaclisib only in patients who had not received previous BTKi, with an objective response rate (ORR) and CR of $70 \%$ and $15.6 \%$, respectively [150], but the results in the most realistic cohort, the BTKi-experienced patients, were disappointing, with ORR and CR of only $35.5 \%$ and $2.9 \%$, respectively [151]. In R/R DLBCL, despite an initial ORR of $30 \%$ in the phase $1 / 2$ study [149], the CITADEL-202 study was prematurely closed due to the high proportion of patients with disease progression during treatment: 95\% (52 out of 55 patients) in the BTKi-naïve arm and 80\% (4 out of 5 patients) in the BTKi-experienced arm [144]. These and other PI3Ki are currently undergoing evaluation in combination with chemotherapy and other targeted drugs (Table 2).

Inhibitors of mTOR (mTORi) and SYK (SYKi) have also been evaluated in MCL and DLBCL. The mTORi temsirolimus was approved in 2009 in Europe for R/R MCL based on its efficacy in two phase 2 studies, showing ORR of 38-41\% in monotherapy [121,122], later confirmed in phase 3 studies, with ORR between 22-47\% [123,126]. Regarding SYKi, fostamatinib showed modest activity in monotherapy in both MCL and DLBCL in a phase $1 / 2$ study, with ORR of $11 \%$ and $22 \%$, respectively [148], and, more recently, TAK-659, a dual inhibitor of SYK and FMS-like tyrosine kinase 3 (FLT3), showed ORR of $28 \%$ in patients with R/R DLBCL [152]. Studies evaluating these and other inhibitors of mTOR and SYK, both in monotherapy and in combination, are summarized in Tables 1 and 2.

Table 2. Clinical trials with targeted BCR inhibition in combinatorial treatments.

\begin{tabular}{|c|c|c|c|c|c|c|c|c|}
\hline Targets & Drug/Regimen & Clinical Trial & Phase & $\mathrm{Nb}$ Pts & Status & Conditions & Response Data & References \\
\hline $\begin{array}{l}\text { BTK } \\
\text { PD1 }\end{array}$ & $\begin{array}{l}\text { Acalabrutinib + } \\
\text { Pembrolizumab }\end{array}$ & NCT02362035 & $1 \& 2$ & 161 & Active & R/R DLBCL & $\begin{array}{c}\text { ORR } 26 \% \\
\text { Discontinuation was } \\
\text { due to PD }(62 \%) \text { and } \\
\text { AEs }(26 \%)\end{array}$ & [153] \\
\hline BTK & Acalabrutinib + R-CHOP & NCT03571308 & $1 \& 2$ & 39 & Active & $\mathrm{nHL}$ & NA & NA \\
\hline BTK & Ibrutinib + R-CHOP & NCT01855750 & 3 & 838 & Completed & $\begin{array}{c}\text { B-cell } \\
\text { Lymphomas }\end{array}$ & ORR $93.6 \%$ & [154] \\
\hline BTK & Ibrutinib + R-ICE & NCT02219737 & 1 & 26 & Completed & DLBCL & ORR $90 \%$ & {$[155]$} \\
\hline BTK & Ibrutinib + CAR-T cell & NCT05020392 & 3 & 24 & Active & $\begin{array}{l}\text { DLBCL, MCL, } \\
\text { CLL, SLL, BL }\end{array}$ & ORR $83 \%$ & {$[156]$} \\
\hline $\begin{array}{l}\text { BTK } \\
\text { PDL1 } \\
4-1 B B \\
\text { CD20 }\end{array}$ & $\begin{array}{c}\text { Ibrutinib + Avelumab + } \\
\text { Utomilumab + Rituximab }\end{array}$ & NCT03440567 & 1 & 16 & Active & $\begin{array}{c}\text { R/R DLBCL, } \\
\text { R/R MCL, } \\
\text { Transformed FL }\end{array}$ & NA & NA \\
\hline BTK & $\begin{array}{c}\text { Ibrutinib }+ \\
\text { Immuno-chemotherapy }\end{array}$ & NCT02055924 & 1 & 85 & Terminated & $\begin{array}{c}\text { B-cell } \\
\text { Lymphomas }\end{array}$ & $\begin{array}{c}\text { CR } 42 \% \\
\text { PR } 25 \% \\
\text { Terminated due to } \\
\text { due to veno } \\
\text { occlusive disease }\end{array}$ & [157] \\
\hline $\begin{array}{c}\text { BTK } \\
\text { JAK1 }\end{array}$ & Ibrutinib + Itacitinib & NCT02760485 & $1 \& 2$ & 33 & Active & $\begin{array}{c}\text { B-cell } \\
\text { Lymphomas }\end{array}$ & ORR $24 \%$ & {$[158]$} \\
\hline BTK & Ibrutinib + Lenalidomide & NCT01955499 & 1 & 34 & Active & $\begin{array}{c}\text { R/R DLBCL, } \\
\text { R/R FL, R/R } \\
\text { MZL, R/R MCL }\end{array}$ & NA & NA \\
\hline $\begin{array}{c}\text { BTK } \\
\text { CD20 }\end{array}$ & Ibrutinib + Rituximab & NCT01980654 & 2 & 80 & Completed & $\begin{array}{c}\text { B-cell } \\
\text { Lymphomas }\end{array}$ & ORR 85-75\% & [159] \\
\hline
\end{tabular}


Table 2. Cont.

\begin{tabular}{|c|c|c|c|c|c|c|c|c|}
\hline Targets & Drug/Regimen & Clinical Trial & Phase & Nb Pts & Status & Conditions & Response Data & References \\
\hline $\begin{array}{l}\text { BTK } \\
\text { CD20 }\end{array}$ & $\begin{array}{c}\text { Ibrutinib + Rituximab + } \\
\text { Bendamustine }\end{array}$ & NCT01479842 & 1 & 48 & Active & $\begin{array}{l}\text { MZL, FL, MCL, } \\
\text { WM }\end{array}$ & $\begin{array}{c}\text { OR } 94 \% \text { in MCL and } \\
37 \% \text { in DLBCL CR } \\
76 \% \text { in MCL and } \\
31 \% \text { in DLBCL }\end{array}$ & [160] \\
\hline BTK & $\begin{array}{l}\text { Ibrutinib + Rituximab + } \\
\text { Lenalidomide }\end{array}$ & NCT02636322 & 2 & 60 & Active & DLBCL & $\begin{array}{c}\text { ORR } 65 \% \\
\text { DOR } 15.9 \text { months }\end{array}$ & [161] \\
\hline $\begin{array}{l}\text { BTK } \\
\text { CD20 }\end{array}$ & $\begin{array}{l}\text { Ibrutinib + Rituximab + } \\
\text { Lenalidomide }\end{array}$ & NCT02077166 & $1 \& 2$ & 134 & Completed & $\mathrm{R} / \mathrm{R} \mathrm{DLBCL}$ & $\begin{array}{c}\text { ORR } 47 \% \\
\text { CR } 28 \% \\
\text { PFS } 21 \text { months } \\
\text { AEs grade > } 3 \text { in less } \\
30 \% \text { patients }\end{array}$ & [162] \\
\hline $\begin{array}{c}\text { BTK } \\
\text { CD20 }\end{array}$ & $\begin{array}{c}\text { Ibrutinib + Rituximab + } \\
\text { Venetoclax }\end{array}$ & NCT03136497 & 1 & 10 & Active & $\mathrm{R} / \mathrm{R} \mathrm{DLBCL}$ & NA & NA \\
\hline BTK & Spebrutinib & NCT01351935 & 1 & 113 & Completed & $\begin{array}{c}\text { B-cell } \\
\text { Lymphomas }\end{array}$ & ORR 53\% & [163] \\
\hline BTK & $\begin{array}{l}\text { Spebrutinib + } \\
\text { Lenalidomide }\end{array}$ & NCT01766583 & 1 & 18 & Completed & $\begin{array}{l}\text { R/R B-cell } \\
\text { Lymphomas }\end{array}$ & NA & NA \\
\hline $\begin{array}{l}\text { BTK } \\
\text { CD20 }\end{array}$ & $\begin{array}{l}\text { Zanubrutinib + } \\
\text { Rituximab }\end{array}$ & NCT03520920 & 2 & 41 & Completed & $\begin{array}{l}\text { MZL, FL, } \\
\text { DLBCL }\end{array}$ & $\begin{array}{c}\text { ORR } 35 \% \\
\text { PFS } 3.38 \text { months }\end{array}$ & [164] \\
\hline $\begin{array}{c}\text { BTK } \\
\text { mTOR }\end{array}$ & $\begin{array}{c}\text { DTRMWXHS-12 + } \\
\text { Everolimus }+ \\
\text { Pomalidomide }\end{array}$ & NCT02900716 & 1 & 48 & Completed & $\begin{array}{c}\text { B-cell } \\
\text { Lymphomas }\end{array}$ & $\begin{array}{l}\text { Well-tolerated and } \\
\text { no DLT achieved }\end{array}$ & [131] \\
\hline $\begin{array}{l}\text { BTK } \\
\text { PI3K }\end{array}$ & Ibrutinib + Umbralisib & NCT02874404 & 2 & 13 & Completed & $\mathrm{R} / \mathrm{R} \mathrm{DLBCL}$ & $\begin{array}{c}\text { ORR 31\% } \\
\text { PFS } 3 \text { months }\end{array}$ & [165] \\
\hline $\begin{array}{l}\text { BTK } \\
\text { PI3K } \\
\text { CD20 }\end{array}$ & $\begin{array}{c}\text { Ibrutinib + Parsaclisib+ } \\
\text { Rituximab+ } \\
\text { Bendamustine }\end{array}$ & NCT03424122 & 1 & 50 & Active & $\begin{array}{c}\text { B-cell } \\
\text { Lymphomas }\end{array}$ & NA & NA \\
\hline $\begin{array}{l}\text { BTK } \\
\text { PI3K }\end{array}$ & Ibrutinib + Umbralisib & NCT02268851 & 1 & 45 & Active & CLL, SLL, MCL & $\begin{array}{c}\text { ORR } 67 \% \\
\text { CR } 19 \% \\
\text { PR } 48 \% \\
\text { AEs grade }>3 \text { in less } \\
\text { than } 10 \%\end{array}$ & [166] \\
\hline $\begin{array}{l}\text { BTK } \\
\text { PI3K } \\
\text { CD20 }\end{array}$ & $\begin{array}{c}\text { Ibrutinib + Umbralisib + } \\
\text { Ublituximab + } \\
\text { Bendamustine }\end{array}$ & NCT02006485 & 1 & 160 & Completed & $\begin{array}{c}\text { B-cell } \\
\text { Lymphomas }\end{array}$ & DOR 20 months & [167] \\
\hline mTOR & $\begin{array}{l}\text { Everolimus + } \\
\text { Lenalidomide }\end{array}$ & NCT01075321 & $1 \& 2$ & 58 & Completed & $\begin{array}{l}\text { MZL, FL, MCL, } \\
\text { WM }\end{array}$ & ORR $27 \%$ & {$[168]$} \\
\hline mTOR & $\begin{array}{l}\text { Everolimus + } \\
\text { Panobinostat }\end{array}$ & NCT00962507 & 1 & 11 & Completed & $\begin{array}{c}\text { B-cell } \\
\text { Lymphomas }\end{array}$ & $\begin{array}{l}\text { ORR } 43 \% \\
\text { CR } 15 \%\end{array}$ & [169] \\
\hline mTOR & $\begin{array}{l}\text { Everolimus + } \\
\text { Panobinostat }\end{array}$ & NCT00978432 & 2 & 50 & Terminated & DLBCL & $\begin{array}{l}\text { Terminated due to } \\
\text { toxicities, which } \\
\text { seemed to outweigh } \\
\text { the benefits }\end{array}$ & [170] \\
\hline mTOR & $\begin{array}{l}\text { Everolimus + } \\
\text { Panobinostat }\end{array}$ & NCT00918333 & $1 \& 2$ & 124 & Completed & $\begin{array}{l}\text { MZL, BL, MCL, } \\
\text { SLL, CLL, ALL, } \\
\text { WM }\end{array}$ & NA & NA \\
\hline $\begin{array}{c}\text { mTOR } \\
\text { CD20 }\end{array}$ & Everolimus + Rituximab & NCT00869999 & 2 & 26 & Completed & DLBCL & $\begin{array}{c}\text { OR } 38 \% \\
\text { SD } 8 \% \\
\text { DOR } 8.1 \text { months }\end{array}$ & {$[171]$} \\
\hline mTOR & Everolimus + Sorafenib & NCT00474929 & $1 \& 2$ & 103 & Completed & $\begin{array}{c}\text { B-cell } \\
\text { Lymphomas }\end{array}$ & $\begin{array}{l}\text { ORR } 30 \% \text { in DLBCL } \\
\text { and } 38 \% \text { in MCL } \\
\text { DOR } 5.7 \text { months }\end{array}$ & [172] \\
\hline mTOR & $\begin{array}{l}\text { Everolimus + } \\
\text { Sotrastaurin }\end{array}$ & NCT01854606 & 1 & 31 & Completed & ABC DLBCL & $\begin{array}{l}\text { Due to suboptimal } \\
\text { tolerability of the } \\
\text { combinations the } \\
\text { phase II is not } \\
\text { conducted }\end{array}$ & NA \\
\hline
\end{tabular}


Table 2. Cont.

\begin{tabular}{|c|c|c|c|c|c|c|c|c|}
\hline Targets & Drug/Regimen & $\begin{array}{l}\text { Clinical } \\
\text { Trial }\end{array}$ & Phase & Nb Pts & Status & Conditions & Response Data & References \\
\hline mTOR & Sirolimus + hyperCVAD & NCT01184885 & Early 1 & 7 & Completed & $\begin{array}{c}\text { ALL, BL, MCL } \\
\text { NA }\end{array}$ & NA & NA \\
\hline $\begin{array}{l}\text { mTOR } \\
\text { CD22 }\end{array}$ & $\begin{array}{c}\text { Temsirolimus }+ \\
\text { Inotuzumab oxogamicin }\end{array}$ & NCT01535989 & 1 & 25 & Completed & $\begin{array}{l}\text { R/R B-cell } \\
\text { Lymphomas }\end{array}$ & $\begin{array}{c}\text { PR 39\% } \\
\text { This drug } \\
\text { combination is not } \\
\text { possible due to } \\
\text { toxicities }\end{array}$ & {$[173]$} \\
\hline $\begin{array}{l}\text { PI3K } \\
\text { CD20 }\end{array}$ & Buparlisib + Rituximab & NCT02049541 & 1 & 18 & Active & $\begin{array}{c}\text { R/R FL, R/R } \\
\text { MZL, R/R MCL, } \\
\text { WM }\end{array}$ & NA & NA \\
\hline $\begin{array}{l}\text { PI3K } \\
\text { SYK }\end{array}$ & Idelalisib + Entospletinib & NCT01796470 & 2 & 66 & Terminated & $\begin{array}{c}\text { B-cell } \\
\text { Lymphomas }\end{array}$ & $\begin{array}{l}\text { Terminated due to } \\
\text { pneumonitis in } 18 \% \\
\text { of patients }\end{array}$ & {$[174]$} \\
\hline SYK & TAK-659 + R-CHOP & NCT03742258 & 1 & 12 & Active & DLBCL & NA & NA \\
\hline
\end{tabular}

Abbreviations: FL, follicular lymphoma; DLBCL, diffuse large B-cell lymphoma; MCL, mantle cell lymphoma; MZL, marginal zone lymphoma; NHL, non-Hodgkin lymphoma; CLL, chronic lymphocytic leukemia; MM, multiple myeloma; WM, waldenstrom's macroglobulinemia; ORR, overall response rate; CR, complete response PR, partial response; SD, stable disease; PD, progressive disease; DOR, duration of response; PFS, progression-free survival; OS, overall survival; AEs, adverse effects; NA, not available.

\section{BTKi- and PI3Ki-Based Combination Therapies in DLBCL and MCL}

In R/R DLBCL, the results of efficacy with BTKi in monotherapy have been modest, with ORR of 38\% in ABC-DLBCL (5\% in GCB-DLBCL) with ibrutinib [134] or 35\% with tirabrutinib, another new generation covalent BTKi [175]. Nevertheless, these results suggested potential benefit in combination, and there are currently several studies ongoing evaluating BTKi with chemotherapy and other targeted agents in DLBCL and other B-cell malignancies (Table 1). Indeed, preclinical studies showed potential synergy and potentially non-overlapping toxicity of the dual inhibition of BCR signaling key kinases, BTK and PI3K [176].

The first attempt to combine BTKi with PI3Ki in a high-risk MCL population was recently published (NCT02268851) [166]. The authors showed that ibrutinib in combination with umbralisib is well tolerated with an expectable and manageable toxicity in a set of $21 \mathrm{MCL}$ patients. Regarding hematological toxicities, cytopenias were frequent and included: neutropenia $(8 / 21(38 \%))$, thrombocytopenia $(10 / 21(48 \%))$, and anemia $(9 / 21$ $(43 \%))$. The non-hematological adverse events (AEs) included diarrhea $(14 / 21(67 \%))$, infection $(7 / 21(33 \%))$, nausea $(9 / 21(43 \%))$, fatigue $(11 / 21(52 \%))$, and transaminitis $(6 / 21$ $(29 \%))$. In the efficacy analysis, the authors observed an ORR of $67 \%(14 / 21)$ and the CR rate of $19 \%(4 / 21)$. Although the doublet was well tolerated, the efficiency data were similar to those previously reported with ibrutinib as monotherapy [166]. Considering the lack of efficacy using the double combination, the authors also explored the ibrutinibumbralisib duet in combination with the type II CD20 antibody ublituximab in R/R B-NHL patients (NCT02006485) [177]. In this study, 46 patients were enrolled ( $\mathrm{n}=6 \mathrm{DLBCL}$ and $n=6 \mathrm{MCL})$. In general, the triplet therapy was well tolerated, and the most frequent adverse effects were diarrhea (59\%), fatigue (50\%), infusion-related reaction ( $43 \%)$, dizziness (37\%), nausea (37\%), cough (35\%), insomnia (33\%), neutropenia (33\%), pyrexia (33\%), thrombocytopenia (28\%), and peripheral oedema (26\%). In MCL patients, $3 / 6(50 \%)$ reach CR and 3/6 (50\%) partial response (PR). Among DLCBL patients, only 1/6 (17\%) has PR while 5/6 (83\%) progressive disease. These data showed the tolerable safety profile of the triplet regimen in MCL and DLBCL; however the highly proliferative nature of these tumors might be responsible for the lack of meaningful responses [177]. The main limitation of this study is the small set of patients; thus, caution should be applied to make any conclusions in this population. The BTKi (TG1701)-PI3Ki (umbralisib)-antiCD20 (ublituximab) triplet combination was also evaluated in a phase 1 parallel dose-escalation 
study (NCT03671590). Preliminary data indicated that the combination is well tolerated and shows enhanced depth of response over TG-1701 monotherapy [178,179]. Recruitment to this study (NCT03671590) continues.

Acalabrutinib was also studied in combination with PI3K inhibitor ACP-319 and was shown to be safe and tolerable in early phase clinical trials in R/R B-cell malignancies, including DLBCL and MCL (NCT02328014) [180]. Additionally, a phase 1b/2 study is underway looking at the combination of acalabrutinib and duvelisib in R/R indolent NHLs (NCT04836832). Furthermore, idelalisib is also under evaluation in combination with ibrutinib and pembrolizumab (anti-PD1) in patients with low-grade B-cell NHLs in a phase II trial (NCT02332980). Parsaclisib is also being evaluated in combination with rituximab, rituximab plus bendamustine, and ibrutinib (NCT03424122). Future translational science will elucidate the mechanistic basis of the outcomes of combinatory BTK and PI3K inhibition to optimize the landscape of B-NHL therapy.

\section{Conclusions and Perspectives}

With the development of genomic sequencing and immunotherapy, the treatment of aggressive B-cell lymphoma entered the era of precision therapy almost two decades ago. Targeting BCR signaling with oral kinase inhibitors has changed the treatment landscape in MCL. In this disease, the introduction of BTK inhibitors represents one of the most important advances in small molecule-based therapies, with high response rates and durable remissions in the relapse setting, and very encouraging results in the frontline setting. Conversely, despite the initial excitement and strong biological rationale, the latter has yet to demonstrate significant improvements in the outcome for DLBCL patients. As an example, single-agent ibrutinib is active and well tolerated in non-GCB DLBCL, but the duration of response is remarkably short in unselected patients, compared to MCL. In addition, in DLBCL, these approaches are often associated with significant toxicities in combination with chemo-immunotherapeutic regimens, such as R-CHOP, probably underlying the biological complexity and aggressiveness of this disease. Thus, durable responses in DLBCL patients will undoubtedly require combination therapies targeting genetically and experimentally validated biologic drivers. In this sense, "chemo-free" combination strategies associating ibrutinib with rituximab and lenalidomide in previously untreated non-GCB cases are showing prolonged responses with some complete responses, suggesting that these new regimens may have a role in frontline therapy. However, longer follow-ups will be required to confirm these promising results.

Besides DLBCL, these combinations may also improve the clinical outcomes of MCL patients, while ensuring manageable toxicity. The most recent trials are taking advantage of the safety profile of second-generation PI3Ki or BTKi, associating them either with secondary agents with a distinct mechanism of action, such as the BCL-2 antagonist venetoclax, the cyclin-dependent kinase (CDK)4/6 inhibitor (palbociclib), or together (ibrutinib + umbralisib or ibrutinib + copanlisib), in order to enhance the blockade of BCR signaling.

Finally, the use of CAR-T and immune checkpoint blockade therapies, such as programmed cell death protein 1 (PD1)/PD1 ligand (PD-L1) antagonists in combination with BTK (and probably PI3K) inhibitors may represent a significant step towards tailored medicine for the clinical management of both MCL and DLBCL.

Supplementary Materials: The following are available online at https:/ / www.mdpi.com/article/10 .3390 / cancers $14040860 /$ s1, Table S1: Recruiting information and preliminary results of clinical trials with targeted-BCR inhibition as single agent or combinatorial treatments [181-192].

Author Contributions: Conceptualization: G.R. and M.L.R.; investigation: N.P.-P., J.C.S. and A.M.-N.; illustration: N.P.-P., J.C.S. and M.L.R.; writing of the original draft: all authors; reviewing and editing: N.P.-P., J.C.S., G.R. and M.L.R.; supervision: G.R. and M.L.R. All authors have read and agreed to the published version of the manuscript. 
Funding: G.R. acknowledges supports from Fondo de Investigación Sanitaria PI18/01383, Spanish Ministry of Science and Innovation, European Regional Development Fund (ERDF) "Una manera de hacer Europa". J.C.S. holds a Sara Borrell research contract from Instituto de Salud Carlos III, Spanish Ministry of Science and Innovation (CD19/00228).

Conflicts of Interest: G.R. received research support from TG Therapeutics and Kancera. Remaining authors declare no conflict of interest.

\section{References}

1. Teras, L.R.; DeSantis, C.E.; Cerhan, J.R.; Morton, L.M.; Jemal, A.; Flowers, C.R. 2016 US lymphoid malignancy statistics by World Health Organization subtypes. CA Cancer J. Clin. 2016, 66, 443-459. [CrossRef]

2. Siegel, R.L.; Miller, K.D.; Jemal, A. Cancer statistics, 2017. CA Cancer J. Clin. 2017, 67, 7-30. [CrossRef] [PubMed]

3. Alizadeh, A.A.; Elsen, M.B.; Davis, R.E.; Ma, C.L.; Lossos, I.S.; Rosenwald, A.; Boldrick, J.C.; Sabet, H.; Tran, T.; Yu, X.; et al. Distinct types of diffuse large B-cell lymphoma identified by gene expression profiling. Nature 2000, 403, 503-511. [CrossRef] [PubMed]

4. Susanibar-Adaniya, S.; Barta, S.K. 2021 Update on Diffuse large B cell lymphoma: A review of current data and potential applications on risk stratification and management. Am. J. Hematol. 2021, 96, 617-629. [CrossRef] [PubMed]

5. Swerdlow, S.H.; Campo, E.; Pileri, S.A.; Lee Harris, N.; Stein, H.; Siebert, R.; Advani, R.; Ghielmini, M.; Salles, G.A.; Zelenetz, A.D.; et al. The 2016 revision of the World Health Organization classification of lymphoid neoplasms. Blood 2016, 127, 2375-2390. [CrossRef] [PubMed]

6. Johnson, N.A.; Savage, K.J.; Ludkovski, O.; Ben-Neriah, S.; Woods, R.; Steidl, C.; Dyer, M.J.S.; Siebert, R.; Kuruvilla, J.; Klasa, R.; et al. Lymphomas with concurrent BCL2 and MYC translocations: The critical factors associated with survival. Blood 2009, 114, 2273-2279. [CrossRef] [PubMed]

7. Savage, K.J.; Johnson, N.A.; Ben-Neriah, S.; Connors, J.M.; Sehn, L.H.; Farinha, P.; Horsman, D.E.; Gascoyne, R.D. MYC gene rearrangements are associated with a poor prognosis in diffuse large B-cell lymphoma patients treated with R-CHOP chemotherapy. Blood 2009, 114, 3533-3537. [CrossRef]

8. Dreyling, M.; Campo, E.; Hermine, O.; Jerkeman, M.; Le Gouill, S.; Rule, S.; Shpilberg, O.; Walewski, J.; Ladetto, M. Newly diagnosed and relapsed mantle cell lymphoma: ESMO Clinical Practice Guidelines for diagnosis, treatment and follow-up. Ann. Oncol. 2017, 28, iv62-iv71. [CrossRef]

9. Küppers, R. Mechanisms of B-cell lymphoma pathogenesis. Nat. Rev. Cancer 2005, 5, 251-262. [CrossRef]

10. Silkenstedt, E.; Dreyling, M. Mantle cell lymphoma-Advances in molecular biology, prognostication and treatment approaches. Hematol. Oncol. 2021, 39, 31-38. [CrossRef]

11. Herrmann, A.; Hoster, E.; Zwingers, T.; Brittinger, G.; Engelhard, M.; Meusers, P.; Reiser, M.; Forstpointner, R.; Metzner, B.; Peter, N.; et al. Improvement of overall survival in advanced stage mantle cell lymphoma. J. Clin. Oncol. 2009, 27, 511-518. [CrossRef]

12. Bhanja, A.; Rey-Suarez, I.; Song, W.; Upadhyaya, A. Bidirectional feedback between BCR signaling and actin cytoskeletal dynamics. FEBS J. 2021. [CrossRef] [PubMed]

13. Kraus, M.; Alimzhanov, M.B.; Rajewsky, N.; Rajewsky, K. Survival of resting mature B lymphocytes depends on BCR signaling via the Ig $\alpha / \beta$ heterodimer. Cell 2004, 117, 787-800. [CrossRef] [PubMed]

14. Kwak, K.; Akkaya, M.; Pierce, S.K. B cell signaling in context. Nat. Immunol. 2019, 20, 963-969. [CrossRef] [PubMed]

15. Lam, K.P.; Kühn, R.; Rajewsky, K. In vivo ablation of surface immunoglobulin on mature B cells by inducible gene targeting results in rapid cell death. Cell 1997, 90, 1073-1083. [CrossRef]

16. Srinivasan, L.; Sasaki, Y.; Calado, D.P.; Zhang, B.; Paik, J.H.; DePinho, R.A.; Kutok, J.L.; Kearney, J.F.; Otipoby, K.L.; Rajewsky, K PI3 Kinase Signals BCR-Dependent Mature B Cell Survival. Cell 2009, 139, 573-586. [CrossRef]

17. Yao, X.R.; Flaswinkel, H.; Reth, M.; Scott, D.W. Immunoreceptor tyrosine-based activation motif is required to signal pathways of receptor-mediated growth arrest and apoptosis in murine B lymphoma cells. J. Immunol. 1995, 155, $652-65261$.

18. Satpathy, S.; Wagner, S.A.; Beli, P.; Gupta, R.; Kristiansen, T.A.; Malinova, D.; Francavilla, C.; Tolar, P.; Bishop, G.A.; Hostager, B.S.; et al. Systems-wide analysis of BCR signalosomes and downstream phosphorylation and ubiquitylation. Mol. Syst. Biol. 2015, 11, 810. [CrossRef]

19. Harwood, N.E.; Batista, F.D. Visualizing the molecular and cellular events underlying the initiation of B-cell activation. Curr. Top. Microbiol. Immunol. 2009, 334, 153-177. [CrossRef]

20. Cheng, P.C.; Dykstra, M.L.; Mitchell, R.N.; Pierce, S.K. A role for lipid rafts in B cell antigen receptor signaling and antigen targeting. J. Exp. Med. 1999, 190, 1549-1560. [CrossRef]

21. Hae, W.S.; Tolar, P.; Pierce, S.K. Membrane heterogeneities in the formation of B cell receptor-Lyn kinase microclusters and the immune synapse. J. Cell Biol. 2008, 182, 367-379. [CrossRef]

22. Efremov, D.G.; Turkalj, S.; Laurenti, L. Mechanisms of b cell receptor activation and responses to $b$ cell receptor inhibitors in $b$ cell malignancies. Cancers 2020, 12, 1396. [CrossRef]

23. Tsubata, T. Ligand recognition determines the role of inhibitory B cell co-receptors in the regulation of B cell homeostasis and autoimmunity. Front. Immunol. 2018, 9, 2276. [CrossRef] 
24. Rhee, I.; Veillette, A. Protein tyrosine phosphatases in lymphocyte activation and autoimmunity. Nat. Immunol. 2012, 13, 439-447. [CrossRef] [PubMed]

25. Mohamed, A.J.; Yu, L.; Bäckesjö, C.M.; Vargas, L.; Faryal, R.; Aints, A.; Christensson, B.; Berglöf, A.; Vihinen, M.; Nore, B.F.; et al Bruton's tyrosine kinase (Btk): Function, regulation, and transformation with special emphasis on the PH domain. Immunol. Rev. 2009, 228, 58-73. [CrossRef]

26. Mohamed, A.J.; Nore, B.F.; Christensson, B.; Smith, C.I.E. Signalling of Bruton's tyrosine kinase, Btk. Scand. J. Immunol. 1999, 49, 113-118. [CrossRef]

27. Niiro, H.; Clark, E.A. Regulation of B-cell fate by antigen-receptor signals. Nat. Rev. Immunol. 2002, 2, 945-956. [CrossRef] [PubMed]

28. McDonald, C.; Xanthopoulos, C.; Kostareli, E. The role of Bruton's tyrosine kinase in the immune system and disease. Immunology 2021, 164, 722-736. [CrossRef]

29. Corneth, O.B.J.; Klein Wolterink, R.G.J.; Hendriks, R.W. BTK signaling in B cell differentiation and autoimmunity. Curr. Top. Microbiol. Immunol. 2015, 393, 67-105. [CrossRef]

30. Burger, J.A.; Wiestner, A. Targeting B cell receptor signalling in cancer: Preclinical and clinical advances. Nat. Rev. Cancer 2018, 18, 148-167. [CrossRef]

31. Wen, T.; Wang, J.; Shi, Y.; Qian, H.; Liu, P. Inhibitors targeting Bruton's tyrosine kinase in cancers: Drug development advances Leukemia 2021, 35, 312-332. [CrossRef] [PubMed]

32. Young, R.M.; Staudt, L.M. Targeting pathological B cell receptor signalling in lymphoid malignancies. Nat. Rev. Drug Discov. 2013, 12, 229-243. [CrossRef] [PubMed]

33. Warsame, A.A.; Aasheim, H.C.; Nustad, K.; Trøen, G.; Tierens, A.; Wang, V.; Randen, U.; Dong, H.P.; Heim, S.; Brech, A.; et al Splenic marginal zone lymphoma with VH1-02 gene rearrangement expresses poly- and self-reactive antibodies with similar reactivity. Blood 2011, 118, 3331-3339. [CrossRef] [PubMed]

34. Craig, V.J.; Arnold, I.; Gerke, C.; Huynh, M.Q.; Wündisch, T.; Neubauer, A.; Renner, C.; Falkow, S.; Müller, A. Gastric MALT lymphoma B cells express polyreactive, somatically mutated immunoglobulins. Blood 2010, 115, 581-591. [CrossRef] [PubMed]

35. Sachen, K.L.; Strohman, M.J.; Singletary, J.; Alizadeh, A.A.; Kattah, N.H.; Lossos, C.; Mellins, E.D.; Levy, S.; Levy, R. Self-antigen recognition by follicular lymphoma B-cell receptors. Blood Blood 2012, 120, 4182-4190. [CrossRef] [PubMed]

36. Chu, C.C.; Catera, R.; Zhang, L.; Didier, S.; Agagnina, B.M.; Damle, R.N.; Kaufman, M.S.; Kolitz, J.E.; Allen, S.L.; Rai, K.R.; et al. Many chronic lymphocytic leukemia antibodies recognize apoptotic cells with exposed nonmuscle myosin heavy chain IIA: Implications for patient outcome and cell of origin. Blood 2010, 115, 3907-3915. [CrossRef]

37. Biernat, M.M.; Wróbel, T. Bacterial infection and non-hodgkin b-cell lymphoma: Interactions between pathogen, host and the tumor environment. Int. J. Mol. Sci. 2021, 22, 7372. [CrossRef]

38. Young, R.M.; Wu, T.; Schmitz, R.; Dawood, M.; Xiao, W.; Phelan, J.D.; Xu, W.; Menard, L.; Meffre, E.; Chan, W.C.C.; et al. Survival of human lymphoma cells requires B-cell receptor engagement by self-antigens. Proc. Natl. Acad. Sci. USA 2015, 112, 13447-13454. [CrossRef]

39. Rui, L.; Schmitz, R.; Ceribelli, M.; Staudt, L.M. Malignant pirates of the immune system. Nat. Immunol. 2011, 12, 933-940. [CrossRef]

40. Davis, R.E.; Ngo, V.N.; Lenz, G.; Tolar, P.; Young, R.M.; Romesser, P.B.; Kohlhammer, H.; Lamy, L.; Zhao, H.; Yang, Y.; et al Chronic active B-cell-receptor signalling in diffuse large B-cell lymphoma. Nature 2010, 463, 88-92. [CrossRef]

41. Lenz, G.; Davis, R.E.; Ngo, V.N.; Lam, L.; George, T.C.; Wright, G.W.; Dave, S.S.; Zhao, H.; Xu, W.; Rosenwald, A.; et al. Oncogenic CARD11 mutations in human diffuse large B cell lymphoma. Science 2008, 319, 1676-1679. [CrossRef] [PubMed]

42. Compagno, M.; Lim, W.K.; Grunn, A.; Nandula, S.V.; Brahmachary, M.; Shen, Q.; Bertoni, F.; Ponzoni, M.; Scandurra, M.; Califano, A.; et al. Mutations of multiple genes cause deregulation of NF-B in diffuse large B-cell lymphoma. Nature 2009, 459, 717-721. [CrossRef] [PubMed]

43. Ngo, V.N.; Young, R.M.; Schmitz, R.; Jhavar, S.; Xiao, W.; Lim, K.H.; Kohlhammer, H.; Xu, W.; Yang, Y.; Zhao, H.; et al. Oncogenically active MYD88 mutations in human lymphoma. Nature 2011, 470, 115-119. [CrossRef] [PubMed]

44. Phelan, J.D.; Young, R.M.; Webster, D.E.; Roulland, S.; Wright, G.W.; Kasbekar, M.; Shaffer, A.L.; Ceribelli, M.; Wang, J.Q.; Schmitz, R.; et al. A multiprotein supercomplex controlling oncogenic signalling in lymphoma. Nature 2018, 560, 387-391. [CrossRef]

45. Choi, J.; Phelan, J.D.; Wright, G.W.; Häupl, B.; Huang, D.W.; Shaffer, A.L.; Young, R.M.; Wang, Z.; Zhao, H.; Yu, X.; et al. Regulation of B cell receptor-dependent NF-kB signaling by the tumor suppressor KLHL14. Proc. Natl. Acad. Sci. USA 2020, 117, 6092-6102. [CrossRef]

46. Rahal, R.; Frick, M.; Romero, R.; Korn, J.M.; Kridel, R.; Chan, F.C.; Meissner, B.; Bhang, H.E.; Ruddy, D.; Kauffmann, A.; et al. Pharmacological and genomic profiling identifies NF-кB-targeted treatment strategies for mantle cell lymphoma. Nat. Med. 2014, 20, 87-92. [CrossRef]

47. Saba, N.S.; Liu, D.; Herman, S.E.M.; Underbayev, C.; Tian, X.; Behrend, D.; Weniger, M.A.; Skarzynski, M.; Gyamfi, J.; Fontan, L.; et al. Pathogenic role of B-cell receptor signaling and canonical NF- $\mathrm{kB}$ activation in mantle cell lymphoma. Blood 2016, 128, 82-92. [CrossRef]

48. Rinaldi, A.; Kwee, I.; Taborelli, M.; Largo, C.; Uccella, S.; Martin, V.; Poretti, G.; Gaidano, G.; Calabrese, G.; Martinelli, G.; et al Genomic and expression profiling identifies the B-cell associated tyrosine kinase Syk as a possible therapeutic target in mantle cell lymphoma. Br. J. Haematol. 2006, 132, 303-316. [CrossRef] 
49. Wu, C.; de Miranda, N.F.; Chen, L.; Wasik, A.M.; Mansouri, L.; Jurczak, W.; Galazka, K.; Dlugosz-Danecka, M.; Machaczka, M.; Zhang, H.; et al. Genetic heterogeneity in primary and relapsed mantle cell lymphomas: Impact of recurrent CARD11 mutations. Oncotarget 2016, 7, 38180-38190. [CrossRef]

50. Honma, K.; Tsuzuki, S.; Nakagawa, M.; Tagawa, H.; Nakamura, S.; Morishima, Y.; Seto, M. TNFAIP3/A20 functions as a novel tumor suppressor gene in several subtypes of non-Hodgkin lymphomas. Blood 2009, 114, 2467-2475. [CrossRef]

51. Havranek, O.; Xu, J.; Köhrer, S.; Wang, Z.; Becker, L.; Comer, J.M.; Henderson, J.; Ma, W.; Ma, J.M.C.; Westin, J.R.; et al. Tonic B-cell receptor signaling in diffuse large B-cell lymphoma. Blood 2017, 130, 995-1006. [CrossRef] [PubMed]

52. Kulathu, Y.; Grothe, G.; Reth, M. Autoinhibition and adapter function of Syk. Immunol. Rev. 2009, 232, 286-299. [CrossRef] [PubMed]

53. Chen, L.; Monti, S.; Juszczynski, P.; Daley, J.; Chen, W.; Witzig, T.E.; Habermann, T.M.; Kutok, J.L.; Shipp, M.A. SYK-dependent tonic B-cell receptor signaling is a rational treatment target in diffuse large B-cell lymphoma. Blood 2008, 111, 2230-2237. [CrossRef] [PubMed]

54. Chen, L.; Monti, S.; Juszczynski, P.; Ouyang, J.; Chapuy, B.; Neuberg, D.; Doench, J.G.; Bogusz, A.M.; Habermann, T.M.; Dogan, A.; et al. SYK Inhibition Modulates Distinct PI3K/AKT- Dependent Survival Pathways and Cholesterol Biosynthesis in Diffuse Large B Cell Lymphomas. Cancer Cell 2013, 23, 826-838. [CrossRef] [PubMed]

55. Greer, E.L.; Brunet, A. FOXO transcription factors at the interface between longevity and tumor suppression. Oncogene 2005, 24, 7410-7425. [CrossRef]

56. Szydlowski, M.; Kiliszek, P.; Sewastianik, T.; Jablonska, E.; Bialopiotrowicz, E.; Gorniak, P.; Polak, A.; Markowicz, S.; Nowak, E.; Grygorowicz, M.A.; et al. FOXO1 activation is an effector of SYK and AKT inhibition in tonic BCR signal-dependent diffuse large B-cell lymphomas. Blood 2016, 127, 739-748. [CrossRef]

57. Rudelius, M.; Pittaluga, S.; Nishizuka, S.; Pham, T.H.T.; Fend, F.; Jaffe, E.S.; Quintanilla-Martinez, L.; Raffeld, M. Constitutive activation of Akt contributes to the pathogenesis and survival of mantle cell lymphoma. Blood 2006, 108, 1668-1676. [CrossRef]

58. Harris, C.M.; Foley, S.E.; Goedken, E.R.; Michalak, M.; Murdock, S.; Wilson, N.S. Merits and Pitfalls in the Characterization of Covalent Inhibitors of Bruton's Tyrosine Kinase. SLAS Discov. 2018, 23, 1040-1050. [CrossRef]

59. Honigberg, L.A.; Smith, A.M.; Sirisawad, M.; Verner, E.; Loury, D.; Chang, B.; Li, S.; Pan, Z.; Thamm, D.H.; Miller, R.A.; et al. The Bruton tyrosine kinase inhibitor PCI-32765 blocks B-cell activation and is efficacious in models of autoimmune disease and B-cell malignancy. Proc. Natl. Acad. Sci. USA 2010, 107, 13075-13080. [CrossRef]

60. Dasmahapatra, G.; Patel, H.; Dent, P.; Fisher, R.I.; Friedberg, J.; Grant, S. The Bruton tyrosine kinase (BTK) inhibitor PCI-32765 synergistically increases proteasome inhibitor activity in diffuse large-B cell lymphoma (DLBCL) and mantle cell lymphoma (MCL) cells sensitive or resistant to bortezomib. Br. J. Haematol. 2013, 161, 43-56. [CrossRef]

61. He, Y.; Li, J.; Ding, N.; Wang, X.; Deng, L.; Xie, Y.; Ying, Z.; Liu, W.; Ping, L.; Zhang, C.; et al. Combination of Enzastaurin and Ibrutinib synergistically induces anti-tumor effects in diffuse large B cell lymphoma. J. Exp. Clin. Cancer Res. 2019, 38, 86. [CrossRef] [PubMed]

62. Yang, Y.; Shaffer, A.L.; Emre, N.C.T.; Ceribelli, M.; Zhang, M.; Wright, G.; Xiao, W.; Powell, J.; Platig, J.; Kohlhammer, H.; et al. Exploiting Synthetic Lethality for the Therapy of ABC Diffuse Large B Cell Lymphoma. Cancer Cell 2012, 21, 723-737. [CrossRef] [PubMed]

63. Barf, T.; Covey, T.; Izumi, R.; Van De Kar, B.; Gulrajani, M.; Van Lith, B.; Van Hoek, M.; De Zwart, E.; Mittag, D.; Demont, D.; et al. Acalabrutinib (ACP-196): A covalent Bruton tyrosine kinase inhibitor with a differentiated selectivity and in vivo potency profile. J. Pharmacol. Exp. Ther. 2017, 363, 240-252. [CrossRef] [PubMed]

64. Harrington, B.K.; Gardner, H.L.; Izumi, R.; Hamdy, A.; Rothbaum, W.; Coombes, K.R.; Covey, T.; Kaptein, A.; Gulrajani, M.; Van Lith, B.; et al. Preclinical evaluation of the novel BTK inhibitor acalabrutinib in canine models of B-cell non-hodgkin lymphoma. PLoS ONE 2016, 11, e0159607. [CrossRef] [PubMed]

65. Spriano, F.; Tarantelli, C.; Gaudio, E.; Gerlach, M.M.; Priebe, V.; Cascione, L.; Bernasconi, E.; Targa, A.; Mascia, M.; Dirnhofer, S.; et al. Single and combined BTK and PI3K $\delta$ inhibition with acalabrutinib and ACP-319 in pre-clinical models of aggressive lymphomas. Br. J. Haematol. 2019, 187, 595-601. [CrossRef] [PubMed]

66. Tarantelli, C.; Zhang, L.; Curti, E.; Gaudio, E.; Spriano, F.; Priebe, V.; Cascione, L.; Arribas, A.J.; Zucca, E.; Rossi, D.; et al. The Bruton tyrosine kinase inhibitor zanubrutinib (BGB-3111) demonstrated synergies with other anti-lymphoma targeted agents. Haematologica 2019, 104, e307-e309. [CrossRef]

67. Li, N.; Sun, Z.; Liu, Y.; Guo, M.; Zhang, Y.; Zhou, D.; Zhang, B.; Su, D.; Zhang, S.; Han, J.; et al. Abstract 2597: BGB-3111 is a novel and highly selective Bruton's tyrosine kinase (BTK) inhibitor. Cancer Res. 2015, 75, 2597. [CrossRef]

68. Gaudio, E.; Tarantelli, C.; Zucca, E.; Rossi, D.; Stathis, A.; Bertoni, F. Abstract 4182: The two novel BTK-inhibitors M2951 and M7583 show in vivo anti-tumor activity in pre-clinical models of B cell lymphoma. Cancer Res. 2017, 77, 4182. [CrossRef]

69. Cerulli, R.A.; Dashnamoorthy, R.; Evens, A.M. The Bruton's Tyrosine Kinase Inhibitor CC-292 in Diffuse Large B-Cell Lymphoma (DLBCL), T-Cell Lymphoma (TCL), and Hodgkin Lymphoma (HL): Induction of Cell Death and Examination of Rational Novel/Novel Therapeutic Combinations. Blood 2014, 124, 1772. [CrossRef]

70. Yasuhiro, T.; Yoshizawa, T.; Daub, H.; Weber, C.; Narita, M.; Kawabata, K. Abstract 2021: ONO-WG-307, a novel, potent and selective inhibitor of Bruton's tyrosine kinase (Btk), results in sustained inhibition of the ERK, AKT and PKD signaling pathways. Cancer Res. 2012, 72, 2021. [CrossRef] 
71. Kozaki, R.; Yoshizawa, T.; Tohda, S.; Yasuhiro, T.; Hotta, S.; Ariza, Y.; Ueda, Y.; Narita, M.; Kawabata, K. Development of a Bruton's Tyrosine Kinase (Btk) Inhibitor, ONO-WG-307: Efficacy in ABC-DLBCL Xenograft Model-Potential Treatment for B-Cell Malignancies. Blood 2011, 118, 3731. [CrossRef]

72. Ribeiro, M.L.; Reyes-Garau, D.; Vinyoles, M.; Profitós Pelejà, N.; Santos, J.C.; Armengol, M.; Fernández-Serrano, M.; Sedó Mor, A.; Bech-Serra, J.J.; Blecua, P.; et al. Antitumor Activity of the Novel BTK Inhibitor TG-1701 Is Associated with Disruption of Ikaros Signaling in Patients with B-cell Non-Hodgkin Lymphoma. Clin. Cancer Res. 2021, 5, 13. [CrossRef] [PubMed]

73. Wu, H.; Wang, W.; Liu, F.; Weisberg, E.L.; Tian, B.; Chen, Y.; Li, B.; Wang, A.; Wang, B.; Zhao, Z.; et al. Discovery of a potent, covalent BTK inhibitor for B-cell lymphoma. ACS Chem. Biol. 2014, 9, 1086-1091. [CrossRef] [PubMed]

74. Woyach, J.A.; Furman, R.R.; Liu, T.-M.; Ozer, H.G.; Zapatka, M.; Ruppert, A.S.; Xue, L.; Li, D.H.-H.; Steggerda, S.M.; Versele, M.; et al. Resistance Mechanisms for the Bruton's Tyrosine Kinase Inhibitor Ibrutinib. N. Engl. J. Med. 2014, 370, 2286-2294. [CrossRef]

75. Eathiraj, S.; Savage, R.; Yu, Y.; Schwartz, B.; Woyach, J.; Johnson, A.; Reiff, S.; Abbadessa, G. Targeting Ibrutinib-Resistant BTKC481S Mutation with ARQ 531, a Reversible Non-Covalent Inhibitor of BTK. Clin. Lymphoma Myeloma Leuk. 2016, 16, S47-S48. [CrossRef]

76. Yu, Y.; Eathiraj, S.; Savage, R.E.; Abbadessa, G.; Reiff, S.D.; Woyach, J.A.; Johnson, A.J.; Schwartz, B. ARQ 531, a Reversible BTK Inhibitor, Demonstrates Potent Anti-Tumor Activity in ABC-DLBCL and GCB-DLBCL biobehavioral aspects of chronic lymphocytic leukemia View project small-molecule inhibitors View project ARQ 531, A Reversible BTK Inhibitor, Demonstr. EHA Congr. 2017, E1400. [CrossRef]

77. Uckun, F.; Dibirdik, I.; Sarkissian, A.; Qazi, S. In vitro and in vivo chemosensitizing activity of LFM-A13, a dual-function inhibitor of Bruton's tyrosine kinase and polo-like kinases, against human leukemic B-cell precursors. Arzneimittel-Forschung/Drug Res. 2011, 61, 252-259. [CrossRef]

78. Lee, N.; Li, Y.; Yuan, C.; Liu, G.; Yue, C. Discovery of HBW-3-10: A potent, orally active, reversible Bruton's tyrosine kinase (BTK) inhibitor with antitumor activity in mice. J. Clin. Oncol. 2021, 39, e15062. [CrossRef]

79. Crawford, J.J.; Zhang, H. Discovery and Development of Non-Covalent, Reversible Bruton's Tyrosine Kinase Inhibitor Fenebrutinib (GDC-0853). ACS Symp. Ser. 2019, 1332, 239-266. [CrossRef]

80. Thieme, E.; Lam, V.; Bruss, N.; Xu, F.; Kurtz, S.E.; Tyner, J.W.; Danilov, A.; Liu, T. Pharmacologic Inhibition of B Cell-ReceptorAssociated Kinases with CG-806 Induces Apoptosis and Metabolic Reprogramming in Aggressive Non-Hodgkin Lymphoma (NHL) Models. Blood 2020, 136, 29. [CrossRef]

81. Asami, T.; Kawahata, W.; Kashimoto, S.; Sawa, M. Abstract B152: CB1763, a highly selective, novel non-covalent BTK inhibitor, targeting ibrutinib-resistant BTK C481S mutant. Mol. Cancer Ther. 2018, 17, B152. [CrossRef]

82. Gomez, E.B.; Wu, W.; Stephens, J.R.; Rosendahl, M.S.; Brandhuber, B.J. In Vivo Pre-Clinical Evaluation of LOXO-305 Alone and in Combination with Venetoclax, Rituximab, R-CHOP or Obinutuzumab on Human Xenograft Lymphoma Tumor Models in Mice. Blood 2020, 136, 32-33. [CrossRef]

83. Brandhuber, B.; Gomez, E.; Smith, S.; Eary, T.; Spencer, S.; Rothenberg, S.M.; Andrews, S. LOXO-305, A Next Generation Reversible BTK Inhibitor, for Overcoming Acquired Resistance to Irreversible BTK Inhibitors. Clin. Lymphoma Myeloma Leuk. 2018, 18 , S216. [CrossRef]

84. Sun, Y.; Ding, N.; Song, Y.; Yang, Z.; Liu, W.; Zhu, J.; Rao, Y. Degradation of Bruton's tyrosine kinase mutants by PROTACs for potential treatment of ibrutinib-resistant non-Hodgkin lymphomas. Leukemia 2019, 33, 2105-2110. [CrossRef] [PubMed]

85. Zhao, Y.; Shu, Y.; Lin, J.; Chen, Z.; Xie, Q.; Bao, Y.; Lu, L.; Sun, N.; Wang, Y. Discovery of novel BTK PROTACs for B-Cell lymphomas. Eur. J. Med. Chem. 2021, 225, 113820. [CrossRef]

86. Tinworth, C.P.; Lithgow, H.; Dittus, L.; Bassi, Z.I.; Hughes, S.E.; Muelbaier, M.; Dai, H.; Smith, I.E.D.; Kerr, W.J.; Burley, G.A.; et al. PROTAC-Mediated Degradation of Bruton's Tyrosine Kinase Is Inhibited by Covalent Binding. ACS Chem. Biol. 2019, 14, 342-347. [CrossRef]

87. Jaime-Figueroa, S.; Buhimschi, A.D.; Toure, M.; Hines, J.; Crews, C.M. Design, synthesis and biological evaluation of Proteolysis Targeting Chimeras (PROTACs) as a BTK degraders with improved pharmacokinetic properties. Bioorganic Med. Chem. Lett. 2020, 30, 126877. [CrossRef]

88. Zorba, A.; Nguyen, C.; Xu, Y.; Starr, J.; Borzilleri, K.; Smith, J.; Zhu, H.; Farley, K.A.; Ding, W.D.; Schiemer, J.; et al. Delineating the role of cooperativity in the design of potent PROTACs for BTK. Proc. Natl. Acad. Sci. USA 2018, 115, E7285-E7292. [CrossRef]

89. Cheng, S.; Coffey, G.; Zhang, X.H.; Shaknovich, R.; Song, Z.; Lu, P.; Pandey, A.; Melnick, A.M.; Sinha, U.; Wang, Y.L. SYK inhibition and response prediction in diffuse large B-cell lymphoma. Blood 2011, 118, 6342-6352. [CrossRef]

90. Suljagic, M.; Longo, P.G.; Bennardo, S.; Perlas, E.; Leone, G.; Laurenti, L.; Efremov, D.G. The Syk inhibitor fostamatinib disodium (R788) inhibits tumor growth in the E $\mu$-TCL1 transgenic mouse model of CLL by blocking antigen-dependent B-cell receptor signaling. Blood 2010, 116, 4894-4905. [CrossRef]

91. Young, R.M.; Hardy, I.R.; Clarke, R.L.; Lundy, N.; Pine, P.; Turner, B.C.; Potter, T.A.; Refaeli, Y. Mouse models of non-hodgkin lymphoma reveal Syk as an important therapeutic target. Blood 2009, 113, 2508-2516. [CrossRef] [PubMed]

92. Ma, J.; Xing, W.; Coffey, G.; Dresser, K.; Lu, K.; Guo, A.; Raca, G.; Pandey, A.; Conley, P.; Yu, H.; et al. Cerdulatinib, a novel dual SYK/JAK kinase inhibitor, has broad anti-tumor activity in both ABC and GCB types of diffuse large B cell lymphoma. Oncotarget 2015, 6, 43881-43896. [CrossRef] [PubMed] 
93. Axelrod, M.J.; Fowles, P.; Silverman, J.; Clarke, A.; Tang, J.; Rousseau, E.; Webb, H.K.; Di Paolo, J. The Combination of Entospletinib and Vincristine Demonstrates Synergistic Activity in a Broad Panel of Hematological Cancer Cell Lines and Anti-Tumor Efficacy in a DLBCL Xenograft Model. Blood 2015, 126, 5123. [CrossRef]

94. Huck, J.; Brake, R.; Tirrell, S.; He, H.; Theisen, M.; Yu, J.; Zhang, M.; Balani, S.; Atienza, J.; Vincent, P.; et al. Antitumor activity of inhibiting SYK kinase with TAK-659, an investigational agent, in DLBCL models. J. Clin. Oncol. 2014, 32, 8580. [CrossRef]

95. Lam, B.; Arikawa, Y.; Cramlett, J.; Dong, Q.; de Jong, R.; Feher, V.; Grimshaw, C.E.; Farrell, P.J.; Hoffman, I.D.; Jennings, A.; et al. Discovery of TAK-659 an orally available investigational inhibitor of Spleen Tyrosine Kinase (SYK). Bioorganic Med. Chem. Lett. 2016, 26, 5947-5950. [CrossRef]

96. Barta, S.K.; Rasco, D.W.; Chen, A.I.; Elkins, S.; Wang, M.; Denis, L.J.; Toker, S.; Usansky, H.; Reddy, S.; Rao, N.S. Clinical activity, safety and tolerability of ASN002, a dual JAK/SYK inhibitor, in patients with non-Hodgkin lymphoma (NHL), myeolfibrosis (MF), chronic lymphocytic leukemia (CLL) and solid tumors. J. Clin. Oncol. 2018, 36, TPS7084. [CrossRef]

97. Brana, I.; Siu, L.L. Clinical development of phosphatidylinositol 3-kinase inhibitors for cancer treatment. BMC Med. 2012, 10, 1-15. [CrossRef]

98. Maira, S.M.; Pecchi, S.; Huang, A.; Burger, M.; Knapp, M.; Sterker, D.; Schnell, C.; Guthy, D.; Nagel, T.; Wiesmann, M.; et al. Identification and characterization of NVP-BKM120, an orally available pan-class I PI3-kinase inhibitor. Mol. Cancer Ther. 2012, 11,317-328. [CrossRef]

99. Narkhede, M.; Cheson, B.D. Copanlisib in the treatment of non-Hodgkin lymphoma. Futur. Oncol. 2020, 16, 1947-1955. [CrossRef]

100. Gaudio, E.; Kwee, I.; Spriano, F.; Tarantelli, C.; Rinaldi, A.; Jourdan, T.; Berthold, M.; Arribas, A.; Stathis, A.; Rossi, D.; et al. The Pan Class-I PI3K Inhibitor Copanlisib Has Preclinical Activity in Mantle Cell Lymphoma, Marginal Zone Lymphoma and Chronic Lymphocytic Leukemia As Single Agent and in Combination with Other Targeted and Conventional Agents. Blood 2016, 128, 4185. [CrossRef]

101. Huang, S.; Nastoupil, L.J.; Guo, H.; Bell, T.; Ahmed, M.; Li, C.J.; Wang, J.; Liu, Y.; Zhang, V.; Kim, C.R.; et al. Pre-Clinical Evaluation of the PI3K-p110 $\beta$ / $\delta$ Inhibitor KA2237 in Mantle Cell Lymphoma. Blood 2016, 128, 1837. [CrossRef]

102. Locatelli, S.L.; Careddu, G.; Serio, S.; Consonni, F.M.; Maeda, A.; Viswanadha, S.; Vakkalanka, S.; Castagna, L.; Santoro, A.; Allavena, P.; et al. Targeting cancer cells and tumor microenvironment in preclinical and clinical models of Hodgkin lymphoma using the dual PI3Kd/G inhibitor RP6530. Clin. Cancer Res. 2019, 25, 1098-1112. [CrossRef] [PubMed]

103. Bertram, K.; Leary, P.J.; Boudesco, C.; Fullin, J.; Stirm, K.; Dalal, V.; Zenz, T.; Tzankov, A.; Müller, A. Inhibitors of Bcl-2 and Bruton's tyrosine kinase synergize to abrogate diffuse large B-cell lymphoma growth in vitro and in orthotopic xenotransplantation models. Leukemia 2021, 1-13. [CrossRef] [PubMed]

104. Jain, N.; Singh, S.; Laliotis, G.; Hart, A.; Muhowski, E.; Kupcova, K.; Chrbolkov, T.; Khashab, T.; Chowdhury, S.M.; Sircar, A.; et al. Targeting phosphatidylinositol 3 kinase-b and $-\mathrm{d}$ for Bruton tyrosine kinase resistance in diffuse large B-cell lymphoma. Blood Adv. 2020, 4, 4382-4392. [CrossRef] [PubMed]

105. Pongas, G.N.; Annunziata, C.M.; Staudt, L.M. PI3K $\delta$ inhibition causes feedback activation of PI3K $\alpha$ in the ABC subtype of diffuse large B-cell lymphoma. Oncotarget 2017, 8, 81794-81802. [CrossRef]

106. Zhu, J.; Ke, K.; Xu, L.; Jin, J. Discovery of a novel phosphoinositide 3-kinase gamma (PI3K $\gamma$ ) inhibitor against hematologic malignancies and theoretical studies on its PI3K $\gamma$-specific binding mechanisms. RSC Adv. 2019, 9, 20207-20215. [CrossRef]

107. Lannutti, B.J.; Meadows, S.A.; Herman, S.E.M.; Kashishian, A.; Steiner, B.; Johnson, A.J.; Byrd, J.C.; Tyner, J.W.; Loriaux, M.M.; Deininger, M.; et al. CAL-101, a p110 selective phosphatidylinositol-3-kinase inhibitor for the treatment of B-cell malignancies, inhibits PI3K signaling and cellular viability. Blood 2011, 117, 591-594. [CrossRef]

108. Faia, K.; White, K.; Murphy, E.; Proctor, J.; Pink, M.; Kosmider, N.; McGovern, K.; Kutok, J. The phosphoinositide-3 kinase (PI3K)- $\delta, \gamma$ inhibitor, duvelisib shows preclinical synergy with multiple targeted therapies in hematologic malignancies. PLoS ONE 2018, 13, e0200725. [CrossRef]

109. Wang, J.; Zhang, V.; Bell, T.; Liu, Y.; Guo, H.; Zhang, L. The Effects of PI3K- $\delta / \gamma$ Inhibitor, Duvelisib, in Mantle Cell Lymphoma in Vitro and in Patient-Derived Xenograft Studies. Blood 2016, 128, 3016. [CrossRef]

110. Deng, C.; McIntosh, C.; Rodriguez, R.; Sportelli, P.; Miskin, H.P.; Vakkalanka, S.; Viswanadha, S.; Lipstein, M.; O'Connor, O.A. The PI3K Delta Inhibitor TGR-1202 and Proteasome Inhibitor Carfilzomib Are Highly Synergistic In Killing Human B- and T-Cell Lymphoma Cells. Blood 2013, 122, 4421. [CrossRef]

111. Normant, E.; Ribeiro, M.L.; Profitos-Peleja, N.; Blecua, P.; Reyes-Garau, D.; Santos, J.C.; Armengol, M.; Fernández-Serrano, M.; Miskin, H.P.; Roue, G. The Ublituximab-Umbralisib (U2) Drug Regimen Potentiates the Activity of the Novel CD47-CD19 Bispecific Antibody, TG-1801, through the Activation of the G Protein-Coupled Receptor EBI2/GPR183. Blood 2021, $138,1196$. [CrossRef]

112. Fan, L.; Wang, C.; Zhao, L.; Wang, Z.; Zhang, X.; Liu, X.; Cao, L.; Xu, W.; Li, J. SHC014748M, a novel selective inhi-bitor of PI3Kס, demonstrates promising preclinical antitumor activity in B cell lymphomas and chronic lymphocytic leukemia. Neoplasia 2020, 22, 714-724. [CrossRef]

113. Younes, A.; Samad, N. Utility of mTOR Inhibition in Hematologic Malignancies. Oncologist 2011, 16, 730-741. [CrossRef] [PubMed]

114. Yazbeck, V.Y.; Buglio, D.; Georgakis, G.V.; Li, Y.; Iwado, E.; Romaguera, J.E.; Kondo, S.; Younes, A. Temsirolimus downregulates p21 without altering cyclin D1 expression and induces autophagy and synergizes with vorinostat in mantle cell lymphoma. Exp. Hematol. 2008, 36, 443-450. [CrossRef] 
115. Haritunians, T.; Mori, A.; O'Kelly, J.; Luong, Q.T.; Giles, F.J.; Koeffler, H.P. Antiproliferative activity of RAD001 (everolimus) as a single agent and combined with other agents in mantle cell lymphoma. Leukemia 2007, 21, 333-339. [CrossRef] [PubMed]

116. Mortensen, D.S.; Fultz, K.E.; Xu, S.; Xu, W.; Packard, G.; Khambatta, G.; Gamez, J.C.; Leisten, J.; Zhao, J.; Apuy, J.; et al. CC-223, a potent and selective inhibitor of mTOR kinase: In vitro and in vivo characterization. Mol. Cancer Ther. 2015, 14, 1295-1305. [CrossRef] [PubMed]

117. Ezell, S.A.; Mayo, M.; Bihani, T.; Tepsuporn, S.; Wang, S.; Passino, M.; Grosskurth, S.E.; Collins, M.; Parmentier, J.; Reimer, C.; et al. Synergistic induction of apoptosis by combination of BTK and dual mTORC1/2 inhibitors in diffuse large B cell lymphoma. Oncotarget 2014, 5, 4990-5001. [CrossRef]

118. Tarantelli, C.; Gaudio, E.; Arribas, A.J.; Kwee, I.; Hillmann, P.; Rinaldi, A.; Cascione, L.; Spriano, F.; Bernasconi, E.; Guidetti, F.; et al. PQR309 is a novel dual PI3K/mTOR inhibitor with preclinical antitumor activity in lymphomas as a single agent and in combination therapy. Clin. Cancer Res. 2018, 24, 120-129. [CrossRef]

119. Wang, M.L.; Rule, S.; Martin, P.; Goy, A.; Auer, R.; Kahl, B.S.; Jurczak, W.; Advani, R.H.; Romaguera, J.E.; Williams, M.E.; et al Targeting BTK with Ibrutinib in Relapsed or Refractory Mantle-Cell Lymphoma. N. Engl. J. Med. 2013, 369, 507-516. [CrossRef]

120. Fisher, R.I.; Bernstein, S.H.; Kahl, B.S.; Djulbegovic, B.; Robertson, M.J.; De Vos, S.; Epner, E.; Krishnan, A.; Leonard, J.P.; Lonial, S.; et al. Multicenter phase II study of bortezomib in patients with relapsed or refractory mantle cell lymphoma. J. Clin. Oncol. 2006, 24, 4867-4874. [CrossRef]

121. Witzig, T.E.; Geyer, S.M.; Ghobrial, I.; Inwards, D.J.; Fonseca, R.; Kurtin, P.; Ansell, S.M.; Luyun, R.; Flynn, P.J.; Morton, R.F.; et al. Phase II trial of single-agent temsirolimus (CCI-779) for relapsed mantle cell lymphoma. J. Clin. Oncol. 2005, 23, 5347-5356. [CrossRef] [PubMed]

122. Ansell, S.M.; Inwards, D.J.; Rowland, K.M.; Flynn, P.J.; Morton, R.F.; Moore, D.F.; Kaufmann, S.H.; Ghobrial, I.; Kurtin, P.J.; Maurer, M.; et al. Low-dose, single-agent temsirolimus for relapsed mantle cell lymphoma: A phase 2 trial in the North Central Cancer Treatment Group. Cancer 2008, 113, 508-514. [CrossRef] [PubMed]

123. Hess, G.; Herbrecht, R.; Romaguera, J.; Verhoef, G.; Crump, M.; Gisselbrecht, C.; Laurell, A.; Offner, F.; Strahs, A.; Berkenblit, A.; et al. Phase III study to evaluate temsirolimus compared with investigator's choice therapy for the treatment of relapsed or refractory mantle cell lymphoma. J. Clin. Oncol. 2009, 27, 3822-3829. [CrossRef] [PubMed]

124. Goy, A.; Sinha, R.; Williams, M.E.; Besisik, S.K.; Drach, J.; Ramchandren, R.; Zhang, L.; Cicero, S.; Fu, T.; Witzig, T.E. Single-agent lenalidomide in patients with mantle-cell lymphoma who relapsed or progressed after or were refractory to bortezomib: Phase II MCL-001 (EMERGE) study. J. Clin. Oncol. 2013, 31, 3688-3695. [CrossRef]

125. Trněný, M.; Lamy, T.; Walewski, J.; Belada, D.; Mayer, J.; Radford, J.; Jurczak, W.; Morschhauser, F.; Alexeeva, J.; Rule, S.; et al. Lenalidomide versus investigator's choice in relapsed or refractory mantle cell lymphoma (MCL-002; SPRINT): A phase 2, randomised, multicentre trial. Lancet Oncol. 2016, 17, 319-331. [CrossRef]

126. Dreyling, M.; Jurczak, W.; Jerkeman, M.; Silva, R.S.; Rusconi, C.; Trneny, M.; Offner, F.; Caballero, D.; Joao, C.; Witzens-Harig, M.; et al. Ibrutinib versus temsirolimus in patients with relapsed or refractory mantle-cell lymphoma: An international, randomised, open-label, phase 3 study. Lancet 2016, 387, 770-778. [CrossRef]

127. Rule, S.; Dreyling, M.; Goy, A.; Hess, G.; Auer, R.; Kahl, B.; Cavazos, N.; Liu, B.; Yang, S.; Clow, F.; et al. Outcomes in 370 patients with mantle cell lymphoma treated with ibrutinib: A pooled analysis from three open-label studies. Br. J. Haematol. 2017, 179, 430-438. [CrossRef]

128. Wang, M.; Rule, S.; Zinzani, P.L.; Goy, A.; Casasnovas, O.; Smith, S.D.; Damaj, G.; Doorduijn, J.; Lamy, T.; Morschhauser, F.; et al. Acalabrutinib in relapsed or refractory mantle cell lymphoma (ACE-LY-004): A single-arm, multicentre, phase 2 trial. Lancet 2018, 391, 659-667. [CrossRef]

129. Song, Y.; Zhou, K.; Zou, D.; Zhou, J.; Hu, J.; Yang, H.; Zhang, H.; Ji, J.; Xu, W.; Jin, J.; et al. Treatment of Patients with Relapsed or Refractory Mantle-Cell Lymphoma with Zanubrutinib, a Selective Inhibitor of Bruton's Tyrosine Kinase. Clin. Cancer Res. 2020, 26, 4216-4224. [CrossRef]

130. Dyer, M.J.; De Vos, S.; Ruan, J.; Flowers, C.; Maddocks, K.J.; Rule, S.; Hamdy, A.M.; Izumi, R.; Slatter, J.G.; Cheung, J.; et al Acalabrutinib monotherapy in patients (pts) with relapsed/refractory (R/R) diffuse large B-cell lymphoma (DLBCL). J. Clin. Oncol. 2018, 36, 7547. [CrossRef]

131. Song, Y.; Schuster, S.J.; He, W.; Zhu, J.; Deng, L.; Sun, Y.; Ding, N.; Wang, X.; Gill, J.; Chatburn, E.T.; et al. Simultaneous Global Phase I Studies of a Differentiated BTK Inhibitor, Dtrmwxhs-12, in Relapsed/Refractory Patients with Chronic Lymphocytic Leukemia and B-Cell Lymphomas. Blood 2017, 130, 4056. [CrossRef]

132. Advani, R.H.; Buggy, J.J.; Sharman, J.P.; Smith, S.M.; Boyd, T.E.; Grant, B.; Kolibaba, K.S.; Furman, R.R.; Rodriguez, S.; Chang, B.Y.; et al. Bruton tyrosine kinase inhibitor ibrutinib (PCI-32765) has significant activity in patients with relapsed/refractory B-cell malignancies. J. Clin. Oncol. 2013, 31, 88-94. [CrossRef] [PubMed]

133. Tobinai, K.; Ogura, M.; Ishizawa, K.; Suzuki, T.; Munakata, W.; Uchida, T.; Aoki, T.; Morishita, T.; Ushijima, Y.; Takahara, S. Safety and tolerability of ibrutinib monotherapy in Japanese patients with relapsed/refractory B cell malignancies. Int. J. Hematol. 2016, 103, 86-94. [CrossRef] [PubMed]

134. Wilson, W.H.; Young, R.M.; Schmitz, R.; Yang, Y.; Pittaluga, S.; Wright, G.; Lih, C.J.; Williams, P.M.; Shaffer, A.L.; Gerecitano, J.; et al. Targeting B cell receptor signaling with ibrutinib in diffuse large B cell lymphoma. Nat. Med. 2015, 21, 922-926. [CrossRef] [PubMed] 
135. Graf, S.A.; Cassaday, R.D.; Morris, K.K.; Behnia, S.; Wu, Q.V.; Voutsinas, J.M.; Lynch, R.C.; Krakow, E.; Rasmussen, H.A.; Chauncey, T.R.; et al. Ibrutinib in Relapsed or Refractory Transformed Indolent B-Cell Non-Hodgkin Lymphoma: Final Results from a Prospective Phase II Study. Blood 2019, 134, 1596. [CrossRef]

136. Rule, S.; Dreyling, M.H.; Goy, A.; Hess, G.; Auer, R.; Kahl, B.S.; Hernandez-Rivas, J.A.; Qi, K.; Deshpande, S.; Parisi, L.; et al. Long-Term Outcomes with Ibrutinib Versus the Prior Regimen: A Pooled Analysis in Relapsed/Refractory (R/R) Mantle Cell Lymphoma (MCL) with up to 7.5 Years of Extended Follow-up. Blood 2019, 134, 1538. [CrossRef]

137. Yang, H.; Xiang, B.; Song, Y.; Zhang, H.; Zhao, W.; Zou, D.; Lv, F.; Bai, O.; Liu, A.; Li, C.; et al. Zanubrutinib monotherapy for patients with relapsed or refractory non-germinal center diffuse large B-cell lymphoma: Results from a phase II, single-arm, multicenter, study. J. Clin. Oncol. 2020, 38, e20051. [CrossRef]

138. Goy, A.; Ribrag, V.; Varga, A.; Witzig, T.E.; Ocio, E.M.; Paz-Ares, L.G.; Mita, M.M.; Meyer, T.; Munster, P.N.; Mahipal, A.; et al. Phase I expansion trial of an oral TORC1/TORC2 inhibitor (CC-223) in diffuse large B-cell lymphoma (DLBCL) and multiple myeloma (MM). J. Clin. Oncol. 2013, 31, 8522. [CrossRef]

139. Kater, A.P.; Tonino, S.H.; Spiering, M.; Chamuleau, M.E.D.; Liu, R.; Adewoye, A.H.; Gao, J.; Dreiling, L.; Xin, Y.; Doorduijn, J.K.; et al. Final results of a phase $1 \mathrm{~b}$ study of the safety and efficacy of the PI3K $\delta$ inhibitor acalisib (GS-9820) in relapsed/refractory lymphoid malignancies. Blood Cancer J. 2018, 8, 16. [CrossRef]

140. Lanasa, M.C.; Glenn, M.; Mato, A.R.; Allgood, S.D.; Wong, S.; Amore, B.; Means, G.; Stevens, E.; Yan, C.; Friberg, G.; et al. First-In-Human Study Of AMG 319, a Highly Selective, Small Molecule Inhibitor Of PI3K $\delta$, In Adult Patients With Relapsed Or Refractory Lymphoid Malignancies. Blood 2013, 122, 678. [CrossRef]

141. Younes, A.; Salles, G.; Martinelli, G.; Bociek, R.G.; Barrigon, D.C.; Barca, E.G.; Turgut, M.; Gerecitano, J.; Kong, O.; Pisal, C.B.; et al. Pan-phosphatidylinositol 3-kinase inhibition with buparlisib in patients with relapsed or refractory non-Hodgkin lymphoma. Haematologica 2017, 102, 2104-2112. [CrossRef] [PubMed]

142. Berdeja, J.G.; Oki, Y.; Patel, M.R.; Copeland, A.; Flinn, I.; Neelapu, S.S.; Viner, J.; Wang, J.; Gerecitano, J.F.; Younes, A. Phase 1 first-in-human trial of oral CUDC-907, a dual inhibitor of PI3K and HDAC, in patients with refractory/relapsed lymphoma or multiple myeloma. J. Clin. Oncol. 2015, 33, 8537. [CrossRef]

143. Nastoupil, L.J.; Neelapu, S.S.; Davis, E.; Samaniego, F.; Fowler, N.H.; Westin, J.R.; Lee, H.J.; Wang, M.; Hagemeister, F.B.; Beer, P.; et al. Results of a First in Human, Dose Ascending, Phase I Study Examining the Safety and Tolerability of KA2237, an Oral PI3K p110 $\beta$ / $\delta$ Inhibitor in Patients with Relapsed/Refractory (R/R) B-Cell Lymphoma. Blood 2019, 134, 4099. [CrossRef]

144. Coleman, M.; Belada, D.; Casasnovas, R.O.; Gressin, R.; Lee, H.P.; Mehta, A.; Munoz, J.; Verhoef, G.; Corrado, C.; DeMarini, D.J.; et al. Phase 2 study of parsaclisib (INCB050465), a highly selective, next-generation PI3K $\delta$ inhibitor, in relapsed or refractory diffuse large B-cell lymphoma (CITADEL-202). Leuk. Lymphoma 2021, 62, 368-376. [CrossRef] [PubMed]

145. Carlo-Stella, C.; Barde, P.; Delarue, R.; Scarfò, L.; Viswanadha, S.; Locatelli, S.; Gandolfi, S.; Pittari, V.; Morello, L.; Magagnoli, M.; et al. Safety and clinical activity of RP6530, a dual PI3K $\delta / \gamma$ inhibitor, in patients with advanced hematologic malignancies: Final analysis of a phase 1 multi-center study. Hematol. Oncol. 2017, 35, 263. [CrossRef]

146. Burris, H.A.; Patel, M.R.; Lanasa, M.C.; Brander, D.; O'Connor, O.A.; Deng, C.; Gutierrez, M.; Jones, S.F.; Kuhn, J.G.; Miskin, H.P.; et al. Activity of TGR-1202, a novel once-daily PI3K $\delta$ inhibitor, in patients with relapsed or refractory hematologic malignancies. J. Clin. Oncol. 2014, 32, 2513. [CrossRef]

147. Burris, H.A.; Flinn, I.; Lunning, M.A.; Vose, J.; Fowler, N.H.; Nastoupil, L.J.; O’Brien, S.M.; Schreeder, M.T.; Patel, M.R.; Fenske, T.; et al. Long-term follow-up of the PI3K $\delta$ inhibitor TGR-1202 to demonstrate a differentiated safety profile and high response rates in CLL and NHL: Integrated-analysis of TGR-1202 monotherapy and combined with ublituximab. J. Clin. Oncol. 2016, 34, 7512. [CrossRef]

148. Friedberg, J.W.; Sharman, J.; Sweetenham, J.; Johnston, P.B.; Vose, J.M.; LaCasce, A.; Schaefer-Cutillo, J.; De Vos, S.; Sinha, R.; Leonard, J.P.; et al. Inhibition of Syk with fostamatinib disodium has significant clinical activity in non-Hodgkin lymphoma and chronic lymphocytic leukemia. Blood 2010, 115, 2578-2585. [CrossRef]

149. Forero-Torres, A.; Ramchandren, R.; Yacoub, A.; Wertheim, M.S.; Edenfield, W.J.; Caimi, P.; Gutierrez, M.; Akard, L.; Escobar, C.; Call, J.; et al. Parsaclisib, a potent and highly selective PI3Kd inhibitor, in patients with relapsed or refractory B-cell malignancies. Blood 2019, 133, 1742-1752. [CrossRef]

150. Mehta, A.; Trněný, M.; Walewski, J.; Ribrag, V.; Dartigeas, C.; Christensen, J.H.; Pane, F.; Rodriguez, G.; Taszner, M.; Venugopal, P.; et al. Efficacy and Safety of Parsaclisib in Patients with Relapsed or Refractory Mantle Cell Lymphoma Not Previously Treated with a BTK Inhibitor: Primary Analysis from a Phase 2 Study (CITADEL-205). Blood 2021, 138, 382. [CrossRef]

151. Mehta, A.; Trněný, M.; Walewski, J.; Ribrag, V.; Dartigeas, C.; Christensen, J.H.; Pane, F.; Rodríguez, G.; Taszner, M.; Venugopal, P.; et al. Phase 2 Study Evaluating the Efficacy and Safety of Parsaclisib in Patients with Relapsed or Refractory Mantle Cell Lymphoma Not Previously Treated with a BTK Inhibitor (CITADEL-205). Blood 2020, 136, 22-23. [CrossRef]

152. Gordon, L.I.; Kaplan, J.B.; Popat, R.; Burris, H.A.; Ferrari, S.; Madan, S.; Patel, M.R.; Gritti, G.; El-Sharkawi, D.; Chau, I.; et al. Phase I Study of TAK-659, an Investigational, Dual SYK/FLT3 Inhibitor, in Patients with B-Cell Lymphoma A C. Clin. Cancer Res. 2020, 26, 3546-3556. [CrossRef] [PubMed]

153. Witzig, T.E.; Maddocks, K.J.; De Vos, S.; Lyons, R.M.; Edenfield, W.J.; Sharman, J.P.; Vose, J.; Yimer, H.A.; Wei, H.; Chan, E.M.; et al. Phase $1 / 2$ trial of acalabrutinib plus pembrolizumab (Pem) in relapsed/refractory ( $\mathrm{r} / \mathrm{r}$ ) diffuse large B-cell lymphoma (DLBCL). J. Clin. Oncol. 2019, 37, 7519. [CrossRef] 
154. Younes, A.; Sehn, L.H.; Johnson, P.; Zinzani, P.L.; Hong, X.; Zhu, J.; Patti, C.; Belada, D.; Samoilova, O.; Suh, C.; et al. Randomized phase III trial of ibrutinib and rituximab plus cyclophosphamide, doxorubicin, vincristine, and prednisone in non-germinal center B-cell diffuse large B-cell lymphoma. J. Clin. Oncol. 2019, 37, 1285-1295. [CrossRef]

155. Sauter, C.S.; Matasar, M.J.; Schoder, H.; Devlin, S.M.; Drullinsky, P.; Gerecitano, J.; Kumar, A.; Noy, A.; Palomba, M.L.; Portlock, C.S.; et al. A phase 1 study of ibrutinib in combination with R-ICE in patients with relapsed or primary refractory DLBCL. Blood 2018, 131, 1805-1808. [CrossRef] [PubMed]

156. Gauthier, J.; Hirayama, A.V.; Purushe, J.; Hay, K.A.; Lymp, J.; Li, D.H.; Yeung, C.C.S.; Sheih, A.; Pender, B.S.; Hawkins, R.M.; et al. Feasibility and efficacy of CD19-targeted CAR T cells with concurrent ibrutinib for CLL after ibrutinib failure. Blood 2020, 135, 1650-1660. [CrossRef]

157. Bonnet, C.M.; Lamy, T.; Fruchart, C.; Le Gouill, S.; Gunzer, K.; Gastinne, T.; Jardin, F.; Karlin, L.; Houot, R.; Dupuis, J.; et al. Ibrutinib in association with R-DHAP/ox for patients with relapsed/refractory b-cell lymphoma: Results of the escalating phase of the BIBLOS phase Ib LYSA study. J. Clin. Oncol. 2018, 36, e19550. [CrossRef]

158. Beatty, G.L.; Shahda, S.; Beck, T.; Uppal, N.; Cohen, S.J.; Donehower, R.; Gabayan, A.E.; Assad, A.; Switzky, J.; Zhen, H.; et al. A Phase $\mathrm{Ib} / \mathrm{II}$ Study of the JAK1 Inhibitor, Itacitinib, plus nab -Paclitaxel and Gemcitabine in Advanced Solid Tumors. Oncologist 2019, 24, 14. [CrossRef]

159. Fowler, N.H.; Nastoupil, L.; De Vos, S.; Knapp, M.; Flinn, I.W.; Chen, R.; Advani, R.H.; Bhatia, S.; Martin, P.; Mena, R.; et al. The combination of ibrutinib and rituximab demonstrates activity in first-line follicular lymphoma. Br. J. Haematol. 2020, 189, 650-660. [CrossRef]

160. Maddocks, K.; Christian, B.; Jaglowski, S.; Flynn, J.; Jones, J.A.; Porcu, P.; Wei, L.; Jenkins, C.; Lozanski, G.; Byrd, J.C.; et al. A phase $1 / 1$ b study of rituximab, bendamustine, and ibrutinib in patients with untreated and relapsed/refractory non-Hodgkin lymphoma. Blood 2015, 125, 242-248. [CrossRef]

161. Westin, J.R.; Nastoupil, L.J.; Fayad, L.; Hagemeister, F.B.; Oki, Y.; Turturro, F.; Ahmed, S.; Rodriguez, M.A.; Lee, H.J.; Steiner, R.E.; et al. Smart Start: Rituximab, Lenalidomide, and Ibrutinib Alone and in Combination with Standard Chemotherapy for Patients with Newly Diagnosed Diffuse Large B-Cell Lymphoma: Final Phase II Results. Blood 2019, 134, 1581. [CrossRef]

162. Ramchandren, R.; Johnson, P.; Ghosh, N.; Ruan, J.; Ardeshna, K.M.; Johnson, R.; Verhoef, G.; Cunningham, D.; de Vos, S.; Kassam, S.; et al. Phase 2 Results of the iR2 Regimen (Ibrutinib, Lenalidomide, and Rituximab) in Patients with Relapsed/Refractory (R/R) Non-Germinal Center B Cell-like (Non-GCB) Diffuse Large B-Cell Lymphoma (DLBCL). Blood 2019, 134, 761. [CrossRef]

163. Brown, J.R.; Harb, W.A.; Hill, B.T.; Gabrilove, J.; Sharman, J.P.; Schreeder, M.T.; Barr, P.M.; Foran, J.M.; Miller, T.P.; Burger, J.A.; et al. Phase I study of single-agent CC-292, a highly selective bruton's tyrosine kinase inhibitor, in relapsed/refractory chronic lymphocytic leukemia. Haematologica 2016, 101, e295-e298. [CrossRef] [PubMed]

164. Zhang, Q.; Tao, R.; Li, Z.; Guo, H.; Ji, M.; Zhang, L.; Huang, J.; Zhong, J.; Zhou, J. Zanubrutinib (BGB-3111) in combination with rituximab in patients with relapsed/refractory nonhodgkin lymphoma. HemaSphere 2020, 4, 596.

165. Dhillon, S.; Keam, S.J. Umbralisib: First Approval. Drugs 2021, 81, 857-866. [CrossRef] [PubMed]

166. Davids, M.S.; Kim, H.T.; Nicotra, A.; Savell, A.; Francoeur, K.; Hellman, J.M.; Bazemore, J.; Miskin, H.P.; Sportelli, P.; Stampleman, L.; et al. Umbralisib in combination with ibrutinib in patients with relapsed or refractory chronic lymphocytic leukaemia or mantle cell lymphoma: A multicentre phase 1-1b study. Lancet Haematol. 2019, 6, e38-e47. [CrossRef]

167. Lunning, M.; Vose, J.; Nastoupil, L.; Fowler, N.; Burger, J.A.; Wierda, W.G.; Schreeder, M.T.; Siddiqi, T.; Flowers, C.R.; Cohen, J.B.; et al. Ublituximab and umbralisib in relapsed/refractory B-cell non-Hodgkin lymphoma and chronic lymphocytic leukemia. Blood 2019, 134, 1811-1820. [CrossRef]

168. Padrnos, L.; Ernst, B.; Dueck, A.C.; Kosiorek, H.E.; Ginos, B.F.; Toro, A.; Johnston, P.B.; Habermann, T.M.; Leis, J.F.; Mikhael, J.R.; et al. A Novel Combination of the mTORC1 Inhibitor Everolimus and the Immunomodulatory Drug Lenalidomide Produces Durable Responses in Patients With Heavily Pretreated Relapsed Lymphoma. Clin. Lymphoma Myeloma Leuk. 2018, 18, 664-672.e2. [CrossRef]

169. Oki, Y.; Buglio, D.; Fanale, M.; Fayad, L.; Copeland, A.; Romaguera, J.; Kwak, L.W.; Pro, B.; De Castro Faria, S.; Neelapu, S.; et al. Phase i study of panobinostat plus everolimus in patients with relapsed or refractory lymphoma. Clin. Cancer Res. 2013, 19, 6882-6890. [CrossRef]

170. Islam, P.; Rizzieri, D.; Lin, C.; de Castro, C.; Diehl, L.; Li, Z.; Moore, J.; Morris, T.; Beaven, A. Phase II Study of Single-Agent and Combination Everolimus and Panobinostat in Relapsed or Refractory Diffuse Large B-Cell Lymphoma. Cancer Investig. 2021, 39, 871-879. [CrossRef]

171. Barnes, J.A.; Jacobsen, E.; Feng, Y.; Freedman, A.; Hochberg, E.P.; LaCasce, A.S.; Armand, P.; Joyce, R.; Sohani, A.R.; Rodig, S.J.; et al. Everolimus in combination with rituximab induces complete responses in heavily pretreated diffuse large B-cell lymphoma. Haematologica 2013, 98, 615-619. [CrossRef] [PubMed]

172. Witzig, T.E.; Reeder, C.B.; Laplant, B.R.; Gupta, M.; Johnston, P.B.; Micallef, I.N.; Porrata, L.F.; Ansell, S.M.; Colgan, J.P.; Jacobsen, E.D.; et al. A phase II trial of the oral mTOR inhibitor everolimus in relapsed aggressive lymphoma. Leukemia 2011, 25, 341-347. [CrossRef] [PubMed]

173. Pirosa, M.C.; Zhang, L.; Hitz, F.; Novak, U.; Hess, D.; Terrot, T.; Pascale, M.; Mazzucchelli, L.; Bertoni, F.; Cavalli, F.; et al. A phase I trial of inotuzumab ozogamicin in combination with temsirolimus in patients with relapsed or refractory CD22-positive B-cell non-Hodgkin lymphomas. Leuk. Lymphoma 2021, 63, 117-123. [CrossRef] [PubMed] 
174. Barr, P.M.; Saylors, G.B.; Spurgeon, S.E.; Cheson, B.D.; Greenwald, D.R.; O’Brien, S.M.; Liem, A.K.D.; Mclntyre, R.E.; Joshi, A.; Abella-Dominicis, E.; et al. Phase 2 study of idelalisib and entospletinib: Pneumonitis limits combination therapy in relapsed refractory CLL and NHL. Blood 2016, 127, 2411-2415. [CrossRef]

175. Walter, H.S.; Rule, S.A.; Dyer, M.J.S.; Karlin, L.; Jones, C.; Cazin, B.; Quittet, P.; Shah, N.; Hutchinson, C.V.; Honda, H.; et al. A phase 1 clinical trial of the selective BTK inhibitor ONO/GS-4059 in relapsed and refractory mature B-cell malignancies. Blood 2016, 127, 411-419. [CrossRef]

176. De Rooij, M.F.M.; Kuil, A.; Kater, A.P.; Kersten, M.J.; Pals, S.T.; Spaargaren, M. Ibrutinib and idelalisib synergistically target BCR-controlled adhesion in MCL and CLL: A rationale for combination therapy. Blood 2015, 125, 2306-2309. [CrossRef]

177. Nastoupil, L.J.; Lunning, M.A.; Vose, J.M.; Schreeder, M.T.; Siddiqi, T.; Flowers, C.R.; Cohen, J.B.; Burger, J.A.; Wierda, W.G.; O'Brien, S.; et al. Tolerability and activity of ublituximab, umbralisib, and ibrutinib in patients with chronic lymphocytic leukaemia and non-Hodgkin lymphoma: A phase 1 dose escalation and expansion trial. Lancet Haematol. 2019, 6, e100-e109. [CrossRef]

178. Cheah, C.Y.; Wickham, N.; Yannakou, C.K.; Lewis, K.L.; Hui, C.-H.; Tang, P.S.; Turpuseema, T.; Miskin, H.P.; Tang, J.-P.; Normant, E.; et al. Phase 1 Study of TG-1701, a Selective Irreversible Inhibitor of Bruton's Tyrosine Kinase (BTK), in Patients with Relapsed/Refractory B-Cell Malignancies. Blood 2019, 134, 4001. [CrossRef]

179. Cheah, C.Y.; Jurczak, W.; Lasica, M.; Wróbel, T.; Cheung, S.; Walewski, J.; Giannopoulos, K.; Yannakou, C.K.; Lewis, K.L.; Dlugosz-Danecka, M.; et al. The Selective Bruton Tyrosine Kinase (BTK) Inhibitor TG-1701 As Monotherapy and in Combination with Ublituximab and Umbralisib (U2) in Patients with B-Cell Malignancies. Blood 2021, 138, 1549. [CrossRef]

180. Barr, P.M.; Smith, S.D.; Roschewski, M.J.; O’Brien, S.M.; Sharman, J.P.; Melear, J.M.; Hamdy, A.M.; Izumi, R.; Slatter, J.G.; Chernyukhin, N.; et al. Acalabrutinib combined with PI3K $\delta$ inhibitor ACP-319 in patients (pts) with relapsed/refractory (R/R) B-cell malignancies. J. Clin. Oncol. 2018, 36, 7518. [CrossRef]

181. Yang, M.; Qian, J.; Huang, J.; Jiao, Y.; Tang, W.; Xu, X.; Xu, W.; Luo, F.R.; Jin, J. PF515 A Phase I Study of the BTK inhibitor abivertinib (AC0010) in patients with relapsed or refractory B-cell lymphoma. HemaSphere 2019, 3, 210. [CrossRef]

182. Hall, T.; Yu, Y.; Eathiraj, S.; Stephens, D.; Flinn, I.; Woyach, J.; Schwartz, B.; Savage, R.E. Abstract LB-018: ARQ 531, a novel and reversible inhibitor of Bruton's tyrosine kinase, displays favorable oral bioavailability and exposure in patients with B-cell malignancies. Cancer Res. 2018, 78. [CrossRef]

183. Jiang, B.; Qi, J.; Song, Y.; Li, Z.; Tu, M.; Ping, L.; Liu, Z.; Bao, H.; Xu, Z.; Qiu, L. Phase 1 clinical trial of the PI3K $\delta$ inhibitor YY-20394 in patients with B-cell hematological malignancies. J. Hematol. Oncol. 2021, 14, 130. [CrossRef] [PubMed]

184. Bailey, N.; Tsomo, T.; Szeto, J.; Bensinger, W.I.; Egan, D.; Hegerova, L.; Mawad, R.; Batchelder, A.; Fesler, J.; Holdread, H.; et al. Acalabrutinib Plus RICE Followed By Autologous Hematopoietic Cell Transplantation and/or Acalabrutinib Maintenance Therapy for Patients with Relapsed/Refractory Diffuse Large B-Cell Lymphoma. Blood 2020, 136, 34. [CrossRef]

185. Hillmen, P.; Qamoos, H.; Uyei, A.; Rothbaum, W.M.; Jurczak, W.; Thieblemont, C.; Byrd, J.C. A Phase 1b-2 Study of KRT-232, a First-in-Class, Oral, Small Molecule Inhibitor of Murine Double Minute 2 (MDM2), in Combination with Acalabrutinib for the Treatment of Relapsed/Refractory (R/R) Chronic Lymphocytic Leukemia (CLL) or R/R Diffuse Large B-Ce. Blood 2020, 136, 23-24. [CrossRef]

186. Shree, T.; Khodadoust, M.S.; Czerwinski, D.K.; Frank, M.J.; Beygi, S.; Long, S.R.; Martin, B.; Levy, R. Intratumoral CpG, Local Radiation, and Oral Ibrutinib Combine to Produce Effective in Situ Vaccination in Patients with Low-Grade B-Cell Lymphoma. Blood 2020, 136, 48. [CrossRef]

187. Minson, A.; Hamad, N.; Butler, J.P.; Westerman, D.A.; Ritchie, D.; Blombery, P.; Seymour, J.F.; Tam, C.S.; Dickinson, M. A Phase II Open-Label, Single Arm Trial to Assess the Efficacy and Safety of the Combination of Tisagenlecleucel and Ibrutinib in Mantle Cell Lymphoma (TARMAC). Blood 2020, 136, 34-35. [CrossRef]

188. Andreadis, C.; Fenske, T.S.; Hill, B.T.; Stiff, P.J.; Grinblatt, D.L.; Hsi, E.D.; Kelley, T.; Richards, K.L.; Kostakoglu, L.; Schöder, H.; et al. Ironclad: A randomized phase III study of ibrutinib (Ibr) or no consolidation following autologous hematopoietic stem cell transplantation (AutoHCT) for relapsed/refractory activated-B-cell (ABC) subtype diffuse large B-cell lymphoma (DLBCL). J. Clin. Oncol. 2017, 35, TPS7566. [CrossRef]

189. Lee, H.J.; Choi, M.Y.; Siddiqi, T.; Wierda, W.G.; Barrientos, J.C.; Lamanna, N.; Goldenberg, A.; Isufi, I.; Tuscano, J.M.; Subbiah, S.; et al. Clinical activity of cirmtuzumab, an anti-ROR1 antibody, in combination with ibrutinib: Interim results of a phase Ib/II study in mantle cell lymphoma (MCL) or chronic lymphocytic leukemia (CLL). J. Clin. Oncol. 2020, 38, 8036. [CrossRef]

190. Shi, Y.-K.; Qin, Y.; Zhang, W.; Wang, X.; Liu, H.; Zang, A.; Yang, L.; Lin, D.; Li, F.; Zhu, H.; et al. 840P Preliminary phase I/II study results of orelabrutinib combined with MIL62 in patients with relapsed or refractory B-cell non-Hodgkin lymphoma. Ann. Oncol. 2021, 32, S778. [CrossRef]

191. Coombs, C.C.; Pagel, J.M.; Shah, N.N.; Lamanna, N.; Lech-Maranda, E.; Eyre, T.A.; Woyach, J.A.; Wierda, W.G.; Cheah, C.Y.; Roeker, L.; et al. CLL-039: Pirtobrutinib (LOXO-305), a Next-Generation, Highly Selective, Non-Covalent BTK Inhibitor in Previously Treated CLL/SLL: Results from the Phase 1/2 BRUIN Study. Clin. Lymphoma Myeloma Leuk. 2021, 21, S315-S316. [CrossRef]

192. Cheah, C.; Jurczak, W.; Lasica, M.; Wickham, N.; Wrobel, T.; Walewski, J.; Yannakou, C.; Cheung, S.; Lewi, K.; Długosz-Danecka, M.; et al. TG-1701 A selective bruton tyrosine kinase (btk) inhibitor, as monotherapy and in combination with ublituximab and umbralisib (u2) in chronic lymphocytic leukemia (cll) and lymphoma. HemaSphere 2021, 5, 286. 